\title{
LEVEL II SCOUR ANALYSIS FOR BRIDGE 2 (BENNCYPARK0002) on PARK STREET, crossing FURNACE BROOK, BENNINGTON, VERMONT
}

U.S. Geological Survey Open-File Report 97-341

Prepared in cooperation with

VERMONT AGENCY OF TRANSPORTATION and

FEDERAL HIGHWAY ADMINISTRATION 


\section{LEVEL II SCOUR ANALYSIS FOR BRIDGE 2 (BENNCYPARK0002) on PARK STREET, crossing FURNACE BROOK, BENNINGTON, VERMONT \\ By SCOTT A. OLSON}

U.S. Geological Survey Open-File Report 97-341

Prepared in cooperation with

VERMONT AGENCY OF TRANSPORTATION

and

FEDERAL HIGHWAY ADMINISTRATION 


\title{
U.S. DEPARTMENT OF THE INTERIOR BRUCE BABBITT, Secretary
}

\author{
U.S. GEOLOGICAL SURVEY \\ Gordon P. Eaton, Director
}

For additional information write to:

District Chief

U.S. Geological Survey 361 Commerce Way

Pembroke, NH 03275-3718
Copies of this report may be purchased from:

U.S. Geological Survey

Branch of Information Services

Open-File Reports Unit

Box 25286

Denver, CO 80225-0286 


\section{CONTENTS}

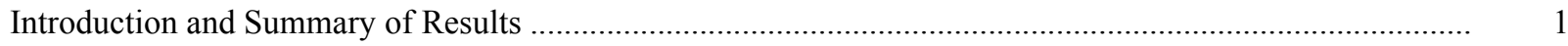

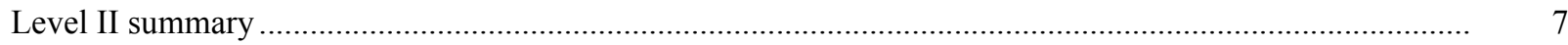

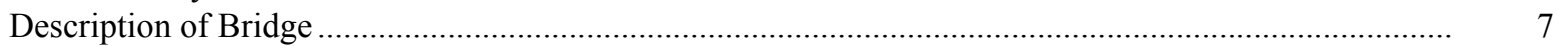

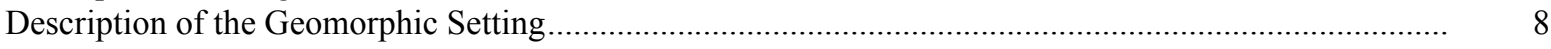

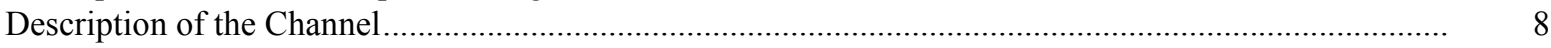

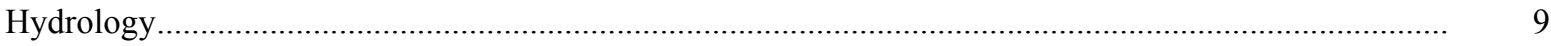

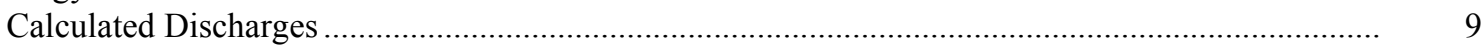

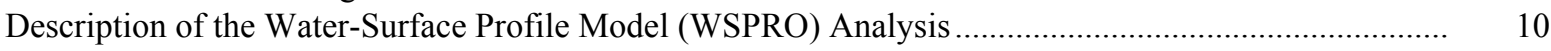

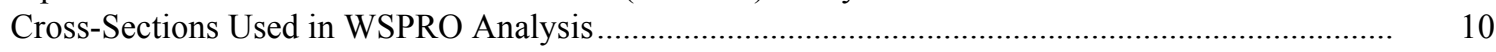

Data and Assumptions Used in WSPRO Model ...................................................................... 11

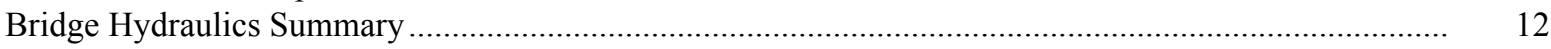

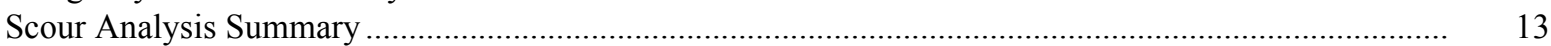

Special Conditions or Assumptions Made in Scour Analysis ...................................................... 13

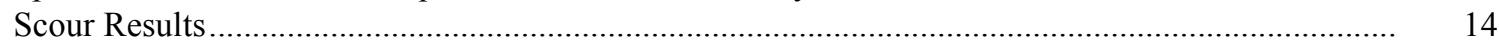

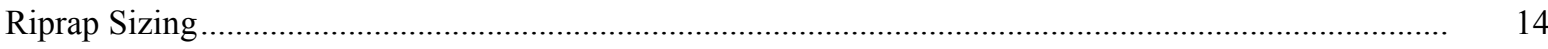

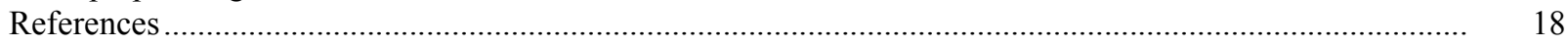

Appendixes:

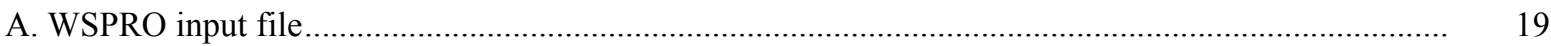

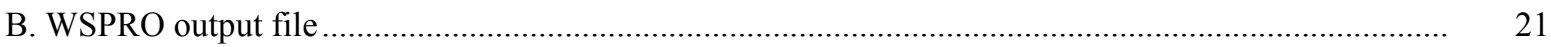

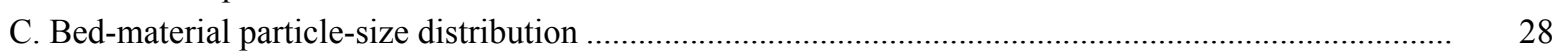

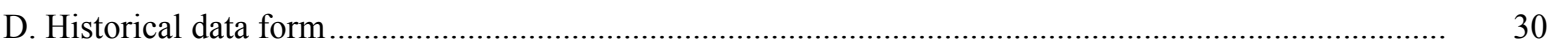

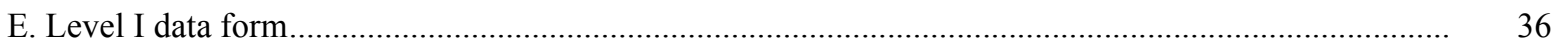

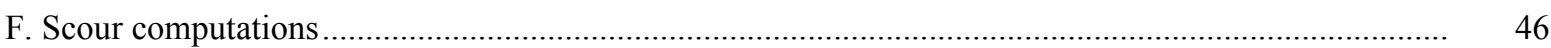

\section{FIGURES}

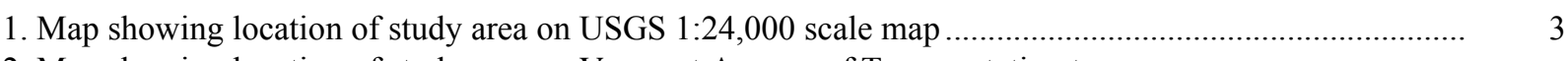

2. Map showing location of study area on Vermont Agency of Transportation town
highway map

3. Structure BENNCYPARK0002 viewed from upstream (August 6, 1996 …........................................... 5

4. Downstream channel viewed from structure BENNCYPARK0002 (August 6, 1996)............................ 5

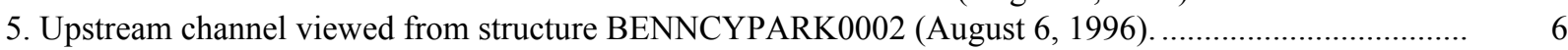

6. Structure BENNCYPARK0002 viewed from downstream (August 6, 1996) ....................................... 6

7. Water-surface profiles for the 100- and 500-year discharges at structure

BENNCYPARK0002 on Park Street, crossing Furnace Brook,

Bennington, Vermont.

8. Scour elevations for the 100- and 500-year discharges at structure

BENNCYPARK0002 on Park Street, crossing Furnace Brook,

Bennington, Vermont.

3
5
6
6
$(5$

\section{TABLES}

1. Remaining footing/pile depth at abutments for the 100-year discharge at structure

BENNCYPARK0002 on Park Street, crossing Furnace Brook,

Bennington, Vermont...

2. Remaining footing/pile depth at abutments for the 500-year discharge at structure

BENNCYPARK0002 on Park Street, crossing Furnace Brook,

Bennington, Vermont. 


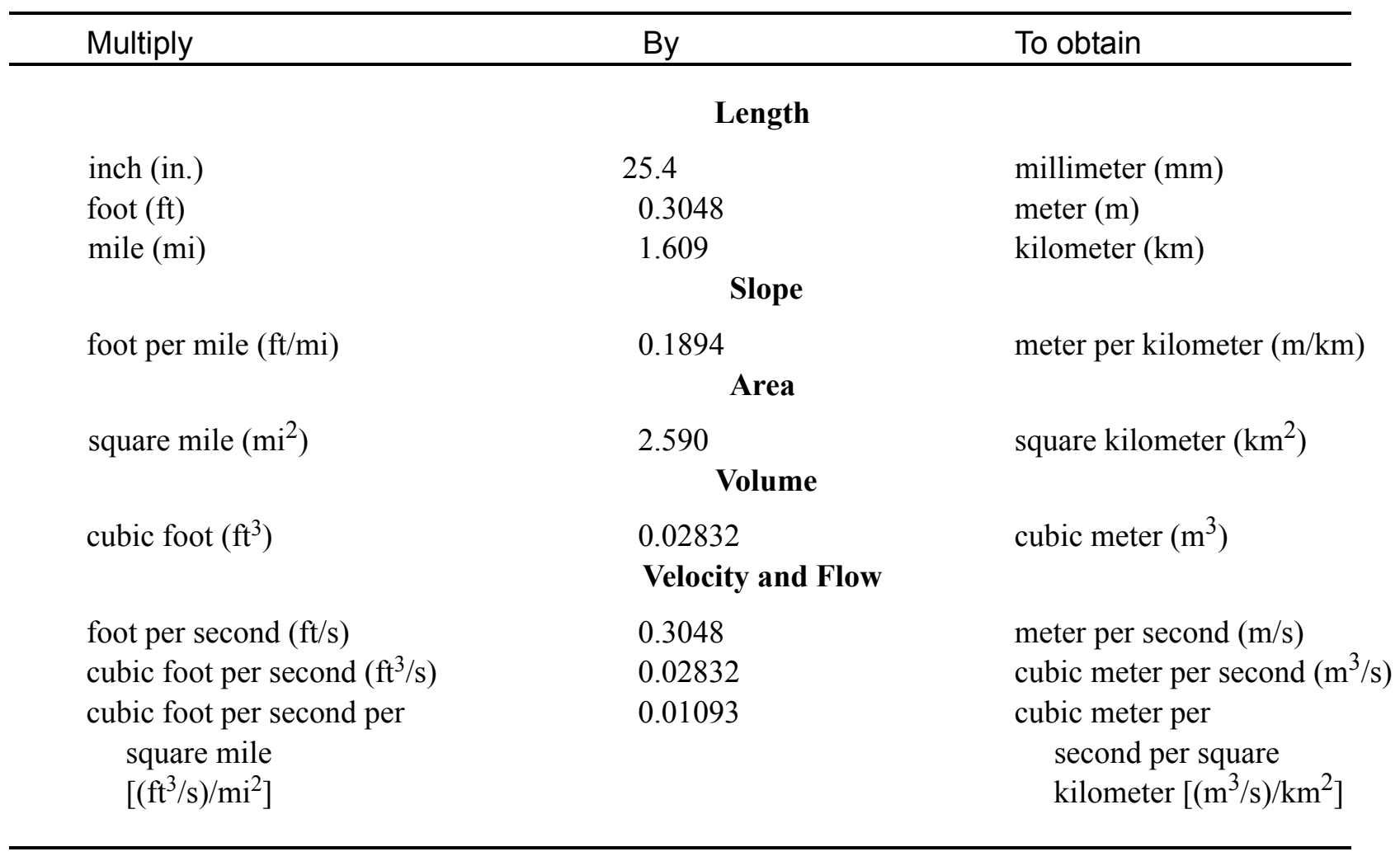

\section{OTHER ABBREVIATIONS}

$\begin{array}{lrlr}\mathrm{BF} & \text { bank full } & \text { LWW } & \text { left wingwall } \\ \mathrm{cfs} & \text { cubic feet per second } & \text { MC } & \text { main channel } \\ \mathrm{D}_{50} & \text { median diameter of bed material } & \text { RAB } & \text { right abutment } \\ \mathrm{DS} & \text { downstream } & \text { RABUT } & \text { face of right abutment } \\ \mathrm{elev} & \text { elevation } & \text { RB } & \text { right bank } \\ \mathrm{f} / \mathrm{p} & \text { flood plain } & \text { ROB } & \text { right overbank } \\ \mathrm{ft}^{2} & \text { square feet } & \text { RWW } & \text { right wingwall } \\ \mathrm{ft} / \mathrm{ft} & \text { feet per foot } & \text { TH } & \text { town highway } \\ \mathrm{JCT} & \text { junction } & \text { UB } & \text { under bridge } \\ \mathrm{LAB} & \text { left abutment } & \text { US } & \text { upstream } \\ \mathrm{LABUT} & \text { face of left abutment } & \text { USGS } & \text { United States Geological Survey } \\ \mathrm{LB} & \text { left bank } & \text { VTAOT Vermont Agency of Transportation } \\ \mathrm{LOB} & \text { left overbank } & \text { WSPRO } & \text { water-surface profile model }\end{array}$

In this report, the words "right" and "left" refer to directions that would be reported by an observer facing downstream. Sea level: In this report, "sea level" refers to the National Geodetic Vertical Datum of 1929-- a geodetic datum derived from a general adjustment of the first-order level nets of the United States and Canada, formerly called Sea Level Datum of 1929.

In the appendices, the above abbreviations may be combined. For example, USLB would represent upstream left bank. 


\title{
LEVEL II SCOUR ANALYSIS FOR BRIDGE 2 (BENNCYPARK0002) ON PARK STREET, CROSSING FURNACE BROOK, BENNINGTON VERMONT
}

\author{
By Scott A. Olson
}

\section{INTRODUCTION AND SUMMARY OF RESULTS}

This report provides the results of a detailed Level II analysis of scour potential at structure BENNCYPARK0002 on the Park Street crossing of Furnace Brook, Bennington, Vermont (figures 1-8). A Level II study is a basic engineering analysis of the site, including a quantitative analysis of stream stability and scour (U.S. Department of Transportation, 1993). Results of a Level I scour investigation also are included in Appendix E of this report. A Level I investigation provides a qualitative geomorphic characterization of the study site. Information on the bridge, gleaned from Vermont Agency of Transportation (VTAOT) files, was compiled prior to conducting Level I and Level II analyses and is found in Appendix D.

The site is in the Green Mountain section of the New England physiographic province in southwestern Vermont. The $12.8-\mathrm{mi}^{2}$ drainage area is a predominantly rural and forested basin. The bridge site is located within an urban setting in the Town of Bennington with buildings, homes, lawns, and pavement on the overbanks.

In the study area, Furnace Brook has a mildly sinuous channel located on a delta and has a slope of approximately $0.01 \mathrm{ft} / \mathrm{ft}$, an average channel top width of $35 \mathrm{ft}$ and an average bank height of $4 \mathrm{ft}$. The predominant channel bed materials are gravel and cobble with a median grain size $\left(\mathrm{D}_{50}\right)$ of $58.4 \mathrm{~mm}(0.192 \mathrm{ft})$. The geomorphic assessment at the time of the Level I and Level II site visit on August 6, 1996, indicated that the reach was unstable. However, in the immediate vicinity of the bridge the reach has been stabilized with bank protection. Upstream of the protection, there is bank cutting and channel scour.

The Park Street crossing of Furnace Brook is a 29-ft-long, two-lane bridge consisting of one 26-foot concrete span (Vermont Agency of Transportation, written communication, December 14, 1995). The width of the bridge opening parallel to the downstream bridge face is 25.3 feet. The bridge is supported by vertical, concrete abutments with no wingwalls. The upstream channel is skewed approximately 45 degrees to the opening while the opening-skew-to-roadway is 10 degrees. 
Scour countermeasures at the site include type- 2 stone fill (less than 36 inches diameter) on the right banks upstream and downstream of the bridge and type- 3 stone fill (less than 48 inches diameter) on the upstream left bank. Additional details describing conditions at the site are included in the Level II Summary and Appendices D and E.

Scour depths and recommended rock rip-rap sizes were computed using the general guidelines described in Hydraulic Engineering Circular 18 (Richardson and others, 1995). Total scour at a highway crossing is comprised of three components: 1) long-term streambed degradation; 2) contraction scour (due to accelerated flow caused by a reduction in flow area at a bridge) and; 3 ) local scour (caused by accelerated flow around piers and abutments). Total scour is the sum of the three components. Equations are available to compute depths for contraction and local scour and a summary of the results of these computations follows.

There was no contraction scour computed for any of the modelled flows. Computed left abutment scour ranged from 2.5 to $5.6 \mathrm{ft}$. with the worst-case scour occurring at the 500year discharge. Computed right abutment scour ranged from 5.6 to $8.4 \mathrm{ft}$. with the worstcase scour also occurring at the 100-year discharge. Additional information on scour depths and depths to armoring are included in the section titled "Scour Results". Scouredstreambed elevations, based on the calculated scour depths, are presented in tables 1 and 2. A cross-section of the scour computed at the bridge is presented in figure 8. Scour depths were calculated assuming an infinite depth of erosive material and a homogeneous particlesize distribution.

It is generally accepted that the Froehlich equation (abutment scour) gives "excessively conservative estimates of scour depths" (Richardson and others, 1995, p. 47). Usually, computed scour depths are evaluated in combination with other information including (but not limited to) historical performance during flood events, the geomorphic stability assessment, existing scour protection measures, and the results of the hydraulic analyses. Therefore, scour depths adopted by VTAOT may differ from the computed values documented herein. 


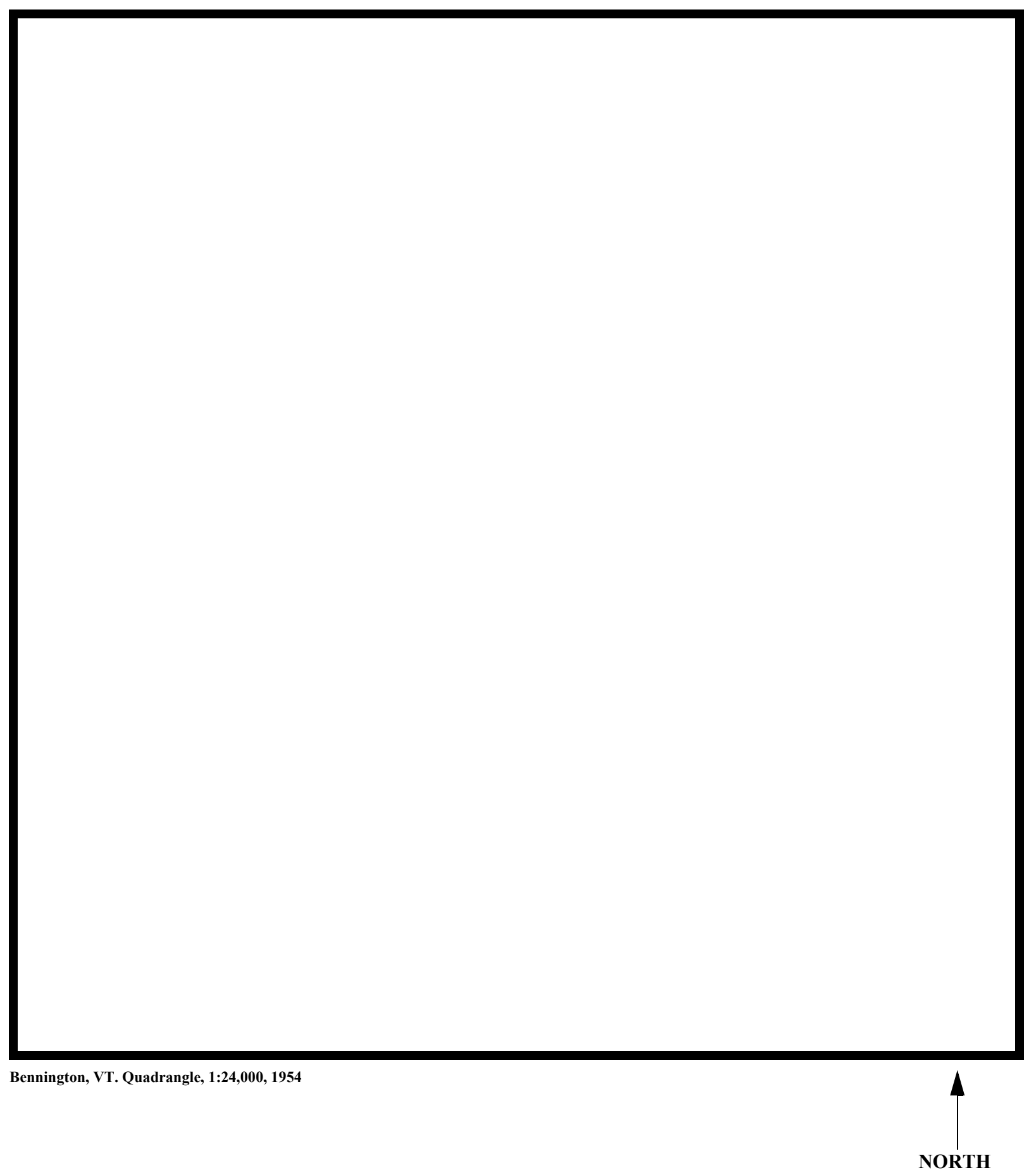

Figure 1. Location of study area on USGS 1:24,000 scale map. 
Figure 2. Location of study area on Vermont Agency of Transportation town highway map. 

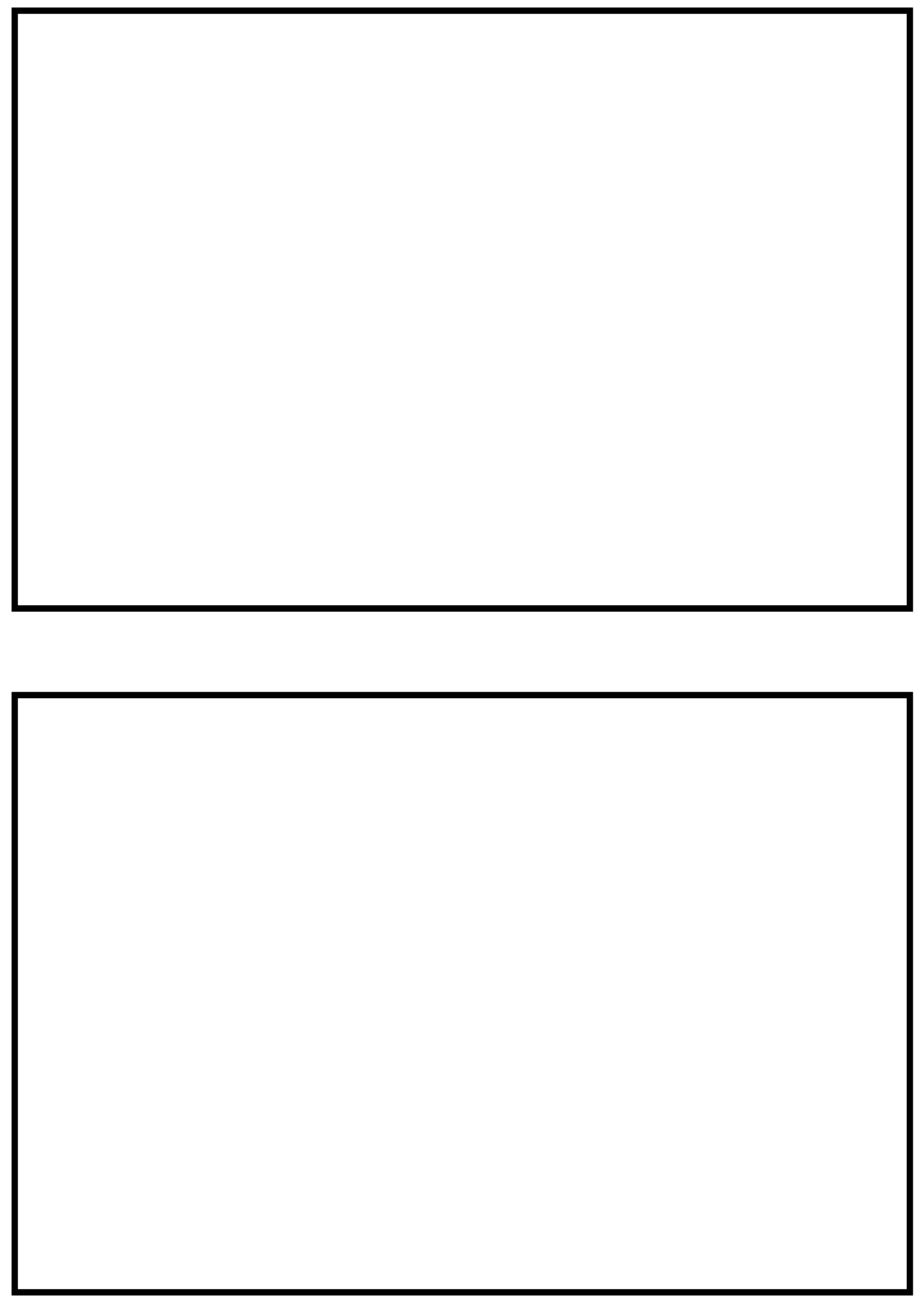

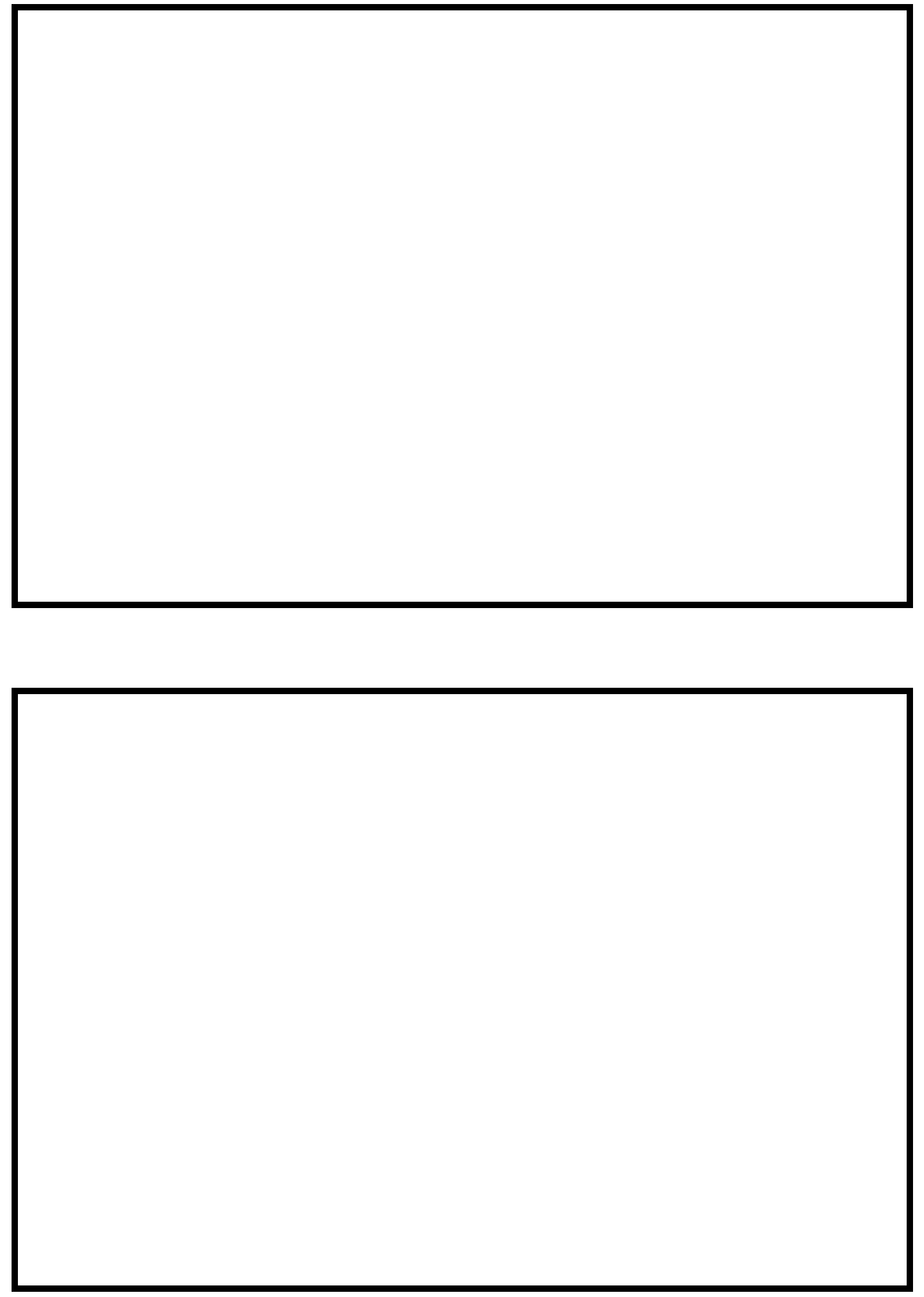


\section{LEVEL II SUMMARY}

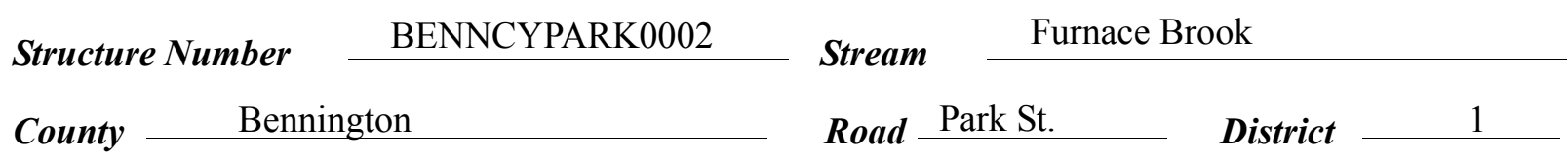

\section{Description of Bridge}

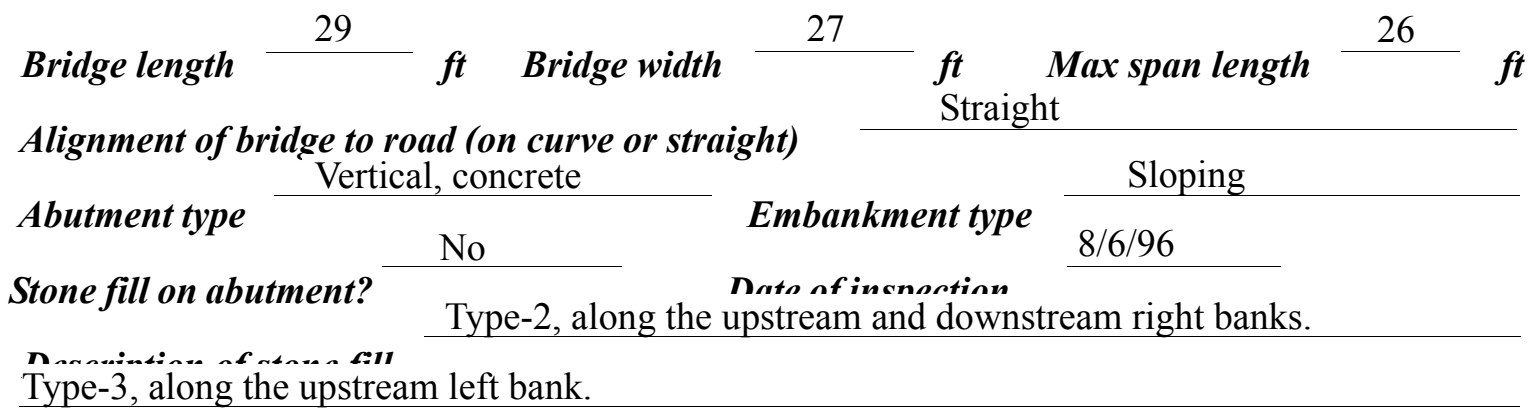

Abutments are concrete. There is 1.5 feet of scour

below the mean thalweg depth along the right abutment.

\section{$\mathrm{N}$} ' survey?
45

$$
\text { Angle }
$$

There is a moderate channel bend at the bridge. The bend results in a channel impact zone on the right abutment and causes scour.

Debris accumulation on bridge at time of Level I or Level II site visit:

\begin{tabular}{|c|c|c|c|}
\hline & $\begin{array}{c}\text { Date af insnortion } \\
8 / 6 / 96 \\
\end{array}$ & $\begin{array}{l}\text { Percent of alommal } \\
\text { blocked inorizontatly }\end{array}$ & $\begin{array}{l}\text { Percent of } 0 \\
\text { blocked verticatty }\end{array}$ \\
\hline el I & $8 / 6 / 96$ & 0 & 0 \\
\hline & \multicolumn{3}{|c|}{ Moderate. The bridge is in an urban setting. } \\
\hline
\end{tabular}

\section{Potential for debris}

August 6, 1996. The low chord is below the tops of banks, increasing the potential for the bridge Doseriho any fonturos noar ar at tho hridos that mav affort flow, (includo ahsorvation dato) to capture debris. 


\section{Description of the Geomorphic Setting}

General topography The channel is located on a delta and thus the channel has wide flood plains, but no valley.

Geomorphic conditions at bridge site: downstream (DS), upstream (US)

Date of inspection $\quad 8 / 6 / 96$

DS left: $\quad$ Low channel bank to a wide flood plain.

DS right: $\quad$ Roadway embankment and a wide flood plain.

US left: $\quad$ Steep channel bank to a wide flood plain.

US right: $\quad$ Steep channel bank to a wide flood plain.

\section{Description of the Channel}

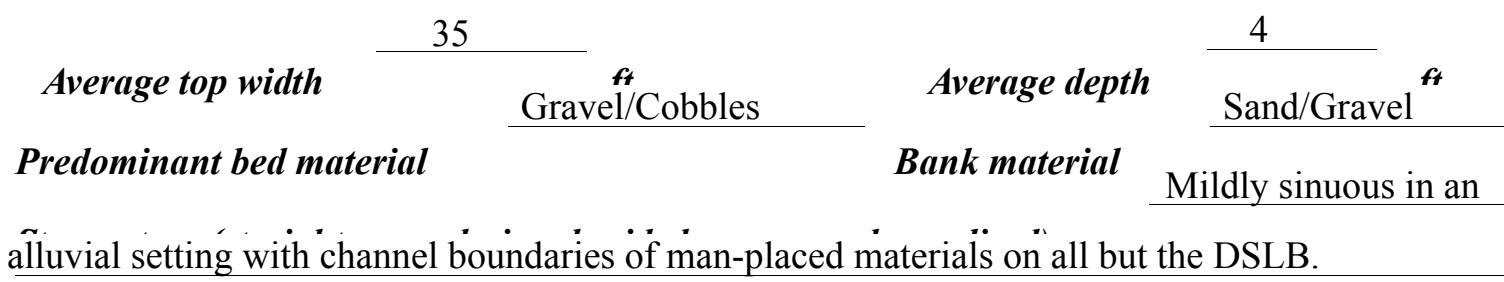

$8 / 6 / 96$

Vegetative co 1 Grass, trees, and residences. More forested further downstream.

DS left: $\quad$ Grass and brush on banks. Grass and a street on the overbank.

DS right: $\quad$ Grass. Forested further upstream.

US left: $\quad$ Grass and a street with some brush in the immediate vicinity of the bridge.

US right: $\mathrm{Y}$

Do banks appear stable? August 6, 1996, Except for the downstream left, the banks in the immediate vicinity of the bridge are protected. However, cut banks and point bars upstream of
date of observatton. the protection resulted in a geomorphic assessment of laterally unstable.

August 6, 1996. At the

downstream face of the bridge there is a narrow concrete slab exposed across most of the Describe any obstructions in channel and date of observation.

channel. This concrete is flush with the channel bed and will not obstruct flow. However, it may impede scour. 


\section{Hydrology}

Drainage area $\frac{12.8}{\boldsymbol{m i}^{2}}$

Percentage of drainage area in physiographic provinces: (approximate)

Physiographic province/section

New England/Green Mountain
Percent of drainage area 100

Is drainage area considered rural or urban? Rural Describe any significant

urbanization: The drainage is rural, but the bridge itself is located in an urban setting.

Is there a USGS gage on the stream of interest?

No

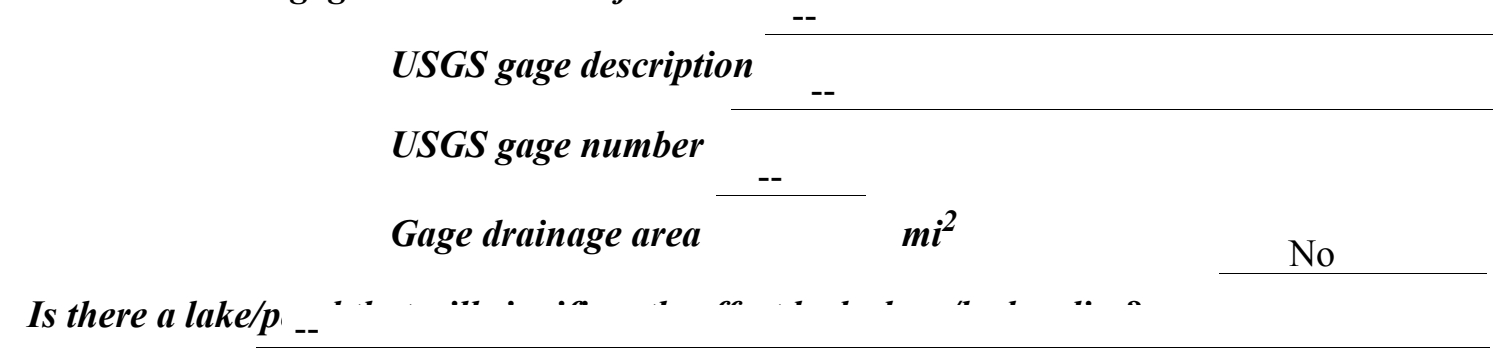

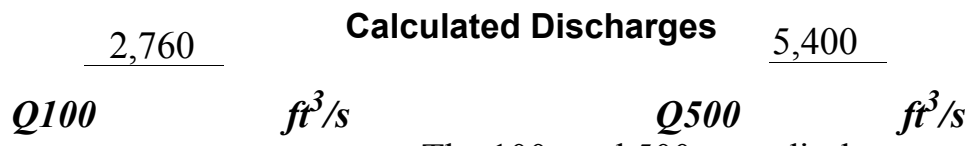

The 100- and 500-year discharges were estimated

using a drainage area relationship ([[12.8/11.0]to the 0.67 power) with flood frequency estimates for bridge 24 over Furnace Brook in Bennington found in the VTAOT database (written communication, May 1994). These discharges were within a range defined by flood frequency curves determined from several empirical methods. (Benson, 1962; Johnson and Tasker, 1974; FHWA, 1983; Potter, 1957a\&b; Talbot, 1887). 


\section{Description of the Water-Surface Profile Model (WSPRO) Analysis}

Datum for WSPRO analysis (USGS survey, sea level, VTAOT plans)

USGS survey

Datum tie between USGS survey and VTAOT plans

Add $500.1 \mathrm{ft}$ to USGS survey

datum to obtain VTAOT plans' datum. Add $147.5 \mathrm{ft}$ to USGS survey to obtain NGVD.

\section{Description of reference marks used to determine USGS datum.}

RM1 is a chiseled X on top of the downstream left corner of the left abutment (elev. $501.57 \mathrm{ft}$, arbitrary survey datum). RM2 is a chiseled $\mathrm{X}$ on top of the upstream right corner of the right abutment (elev. $501.37 \mathrm{ft}$, arbitrary survey datum).

\section{Cross-Sections Used in WSPRO Analysis}

\begin{tabular}{cccl}
\hline${ }^{1}$ Cross-section & $\begin{array}{c}\text { Section } \\
\text { Reference } \\
\text { Distance } \\
\text { (SRD) in feet }\end{array}$ & $\begin{array}{c}{ }^{2} \text { Cross-section } \\
\text { development }\end{array}$ & \multicolumn{1}{c}{ Comments } \\
\hline EXITX & -24 & 1 & Exit section \\
FULLV & 0 & 2 & $\begin{array}{l}\text { Downstream Full-valley } \\
\text { section (Templated from } \\
\text { EXITX) }\end{array}$ \\
BRIDG & 0 & 1 & Bridge section \\
RDWAY & 21 & 1 & Road Grade section \\
APPRO & 70 & 1 & Approach section \\
\hline
\end{tabular}

${ }^{1}$ For location of cross-sections see plan-view sketch included with Level I field form, Appendix E. For more detail on how cross-sections were developed see WSPRO input file. 


\section{Data and Assumptions Used in WSPRO Model}

Hydraulic analyses of the reach were done by use of the Federal Highway Administration's WSPRO step-backwater computer program (Shearman and others, 1986, and Shearman, 1990). The analyses reported herein reflect conditions existing at the site at the time of the study. Furthermore, in the development of the model it was necessary to assume no accumulation of debris or ice at the site. Results of the hydraulic model are presented in the Bridge Hydraulic Summary, Appendix B, and figure 7.

Channel roughness factors (Manning's " $\mathrm{n}$ ") used in the hydraulic model were estimated using field inspections at each cross section following the general guidelines described by Arcement and Schneider (1989). Final adjustments to the values were made during the modelling of the reach. Channel " $\mathrm{n}$ " values for the reach ranged from 0.035 to 0.045 , and overbank " $\mathrm{n}$ " values ranged from 0.035 to 0.070 .

Critical depth at the exit section (EXITX) was assumed as the starting water surface for the 100- and 500-year events. Normal depth at the exit section was assumed as the starting water surface of the incipient roadway-overtopping discharge. Normal depth at the exit section for all modelled discharges was computed by use of the slope-conveyance method outlined in the user's manual for WSPRO (Shearman, 1990). The slope used was $0.0149 \mathrm{ft} / \mathrm{ft}$ which determined from surveyed thalweg points downstream of the bridge. The resulting normal water-surface elevations for the 100- and 500-year discharges were within $0.5 \mathrm{ft}$ below critical depth.

For the 100- and 500-year discharges modelled at this site, WSPRO computes flow through the bridge using a submerged orifice equation. This equation incorporates the head on the downstream side of the bridge into the computation. Although the downstream low chord is submerged, the downstream water surface is at or below critical depth which indicates that downstream conditions are not affecting flow through the bridge. Thus, the submerged orifice equation is not entirely appropriate. 


\section{Bridge Hydraulics Summary}

$\begin{array}{llll}\text { Average bridge embankment elevation } & 500.3 & f t \\ \text { Average low steel elevation } & 498.2 & \boldsymbol{f t}\end{array}$

100-year discharge $\quad 2,760 \quad \mathrm{ft}^{3} / \mathrm{s}$

Water-surface elevation in bridge opening $498.3 \quad f t$

Road overtopping? ___ Y Discharge over road __ 2,100 $\mathrm{ft}^{3} / \mathrm{s}$

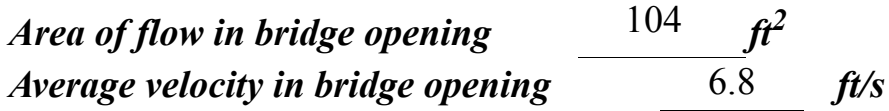

Maximum WSPRO tube velocity at bridge $\quad 8.6 \quad \mathrm{ft} / \mathrm{s}$

Water-surface elevation at Approach section with bridge 501.4

Water-surface elevation at Approach section without bridge $\quad 501.0$

Amount of backwater caused by bridge $\quad 0.4$ it

500-year discharge $\quad 5,400 \quad \mathrm{ft}^{3} / \mathrm{s}$

Water-surface elevation in bridge opening $\quad 498.3 \mathrm{ft}$

Road overtopping? ___ Y Discharge over road _ 4,650 $\boldsymbol{f t}^{3} / \mathrm{s}$

Area of flow in bridge opening $\quad 104 \quad \mathrm{ft}^{2}$

Average velocity in bridge opening $6.2 \mathrm{ft} / \mathrm{s}$

Maximum WSPRO tube velocity at bridge 7.8 , 's

Water-surface elevation at Approach section with bridge $\quad 502.2$

Water-surface elevation at Approach section without bridge $\quad 501.8$

Amount of backwater caused by bridge 0.4 .

Incipient overtopping discharge $\quad 770 \quad \mathrm{ft}^{3} / \mathrm{s}$

Water-surface elevation in bridge opening $498.3 \quad t$

Area of flow in bridge opening $\quad 104 \quad \mathrm{ft}^{2}$

Average velocity in bridge opening $\quad 7.4 \quad \mathrm{ft} / \mathrm{s}$

Maximum WSPRO tube velocity at bridge $\quad 9.4 \mathrm{ft} / \mathrm{s}$

Water-surface elevation at Approach section with bridge

Water-surface elevation at Approach section without bridge

Amount of backwater caused by bridge $\quad \begin{array}{ll}1.0 \\ \text { it }\end{array}$

499.7

498.7 


\section{Scour Analysis Summary}

\section{Special Conditions or Assumptions Made in Scour Analysis}

Scour depths were computed using the general guidelines described in Hydraulic Engineering Circular 18 (Richardson and others, 1995). Scour depths were calculated assuming an infinite depth of erosive material and a homogeneous particle-size distribution. The results of the scour analysis are presented in tables 1 and 2 and a graph of the scour depths is presented in figure 8 .

All modelled discharges resulted in orifice flow. Contraction scour at bridges with orifice flow is best estimated by use of the Chang pressure-flow scour equation (oral communication, J. Sterling Jones, October 4, 1996). Thus, contraction scour was computed by use of the Chang equation (Richardson and others, 1995, p. 145-146). The contraction scour results for all modelled flows using the Chang equation was zero feet. The results of Laursen's clear-water contraction scour equation (Richardson and others, 1995, p. 32, equation 20) were also computed and can be found in Appendix F.

Scour at the right abutment was computed by use of the Froehlich equation (Richardson and others, 1995, p. 48, equation 28). Variables for the Froehlich equation include the Froude number of the flow approaching the embankments, the length of the embankment blocking flow, and the depth of flow approaching the embankment less any roadway overtopping.

Scour at the left abutment was computed by use of the HIRE equation (Richardson and others, 1995, p. 49, equation 29) because the HIRE equation is recommended when the length to depth ratio of the embankment blocking flow exceeds 25 . The variables used by the HIRE abutment-scour equation are defined the same as those defined for the Froehlich abutment-scour equation. 


\section{Scour Results}

100-yr discharge 500-yrdischarge

Incipient

Contraction scour:

(Scour depths in feet)

Main channel

Live-bed scour

Clear-water scour

Depth to armoring

Left overbank

Right overbank
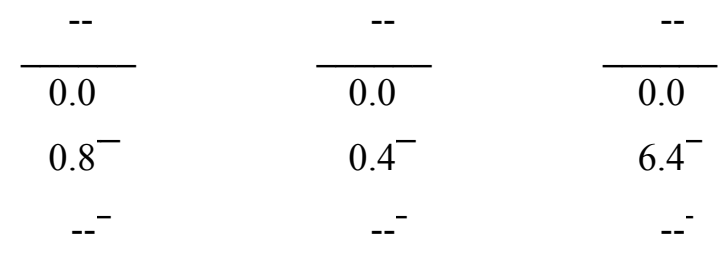

overtopping

discharge

Local scour:

Abutment scour

Left abutment

4.7

5.6

2.5

8.4

$8.1-$

5.6-

Right abutment

Pier scour

Pier 1

Pier 2

Pier 3

\section{Riprap Sizing}

Abutments:

Left abutment

Right abutment

Piers:

Pier 1

Pier 2

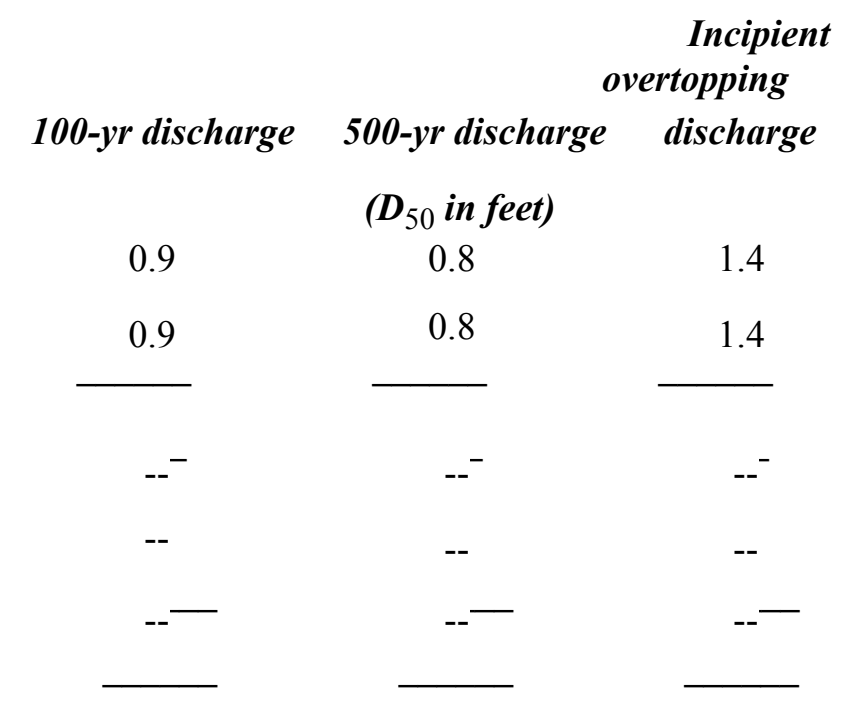




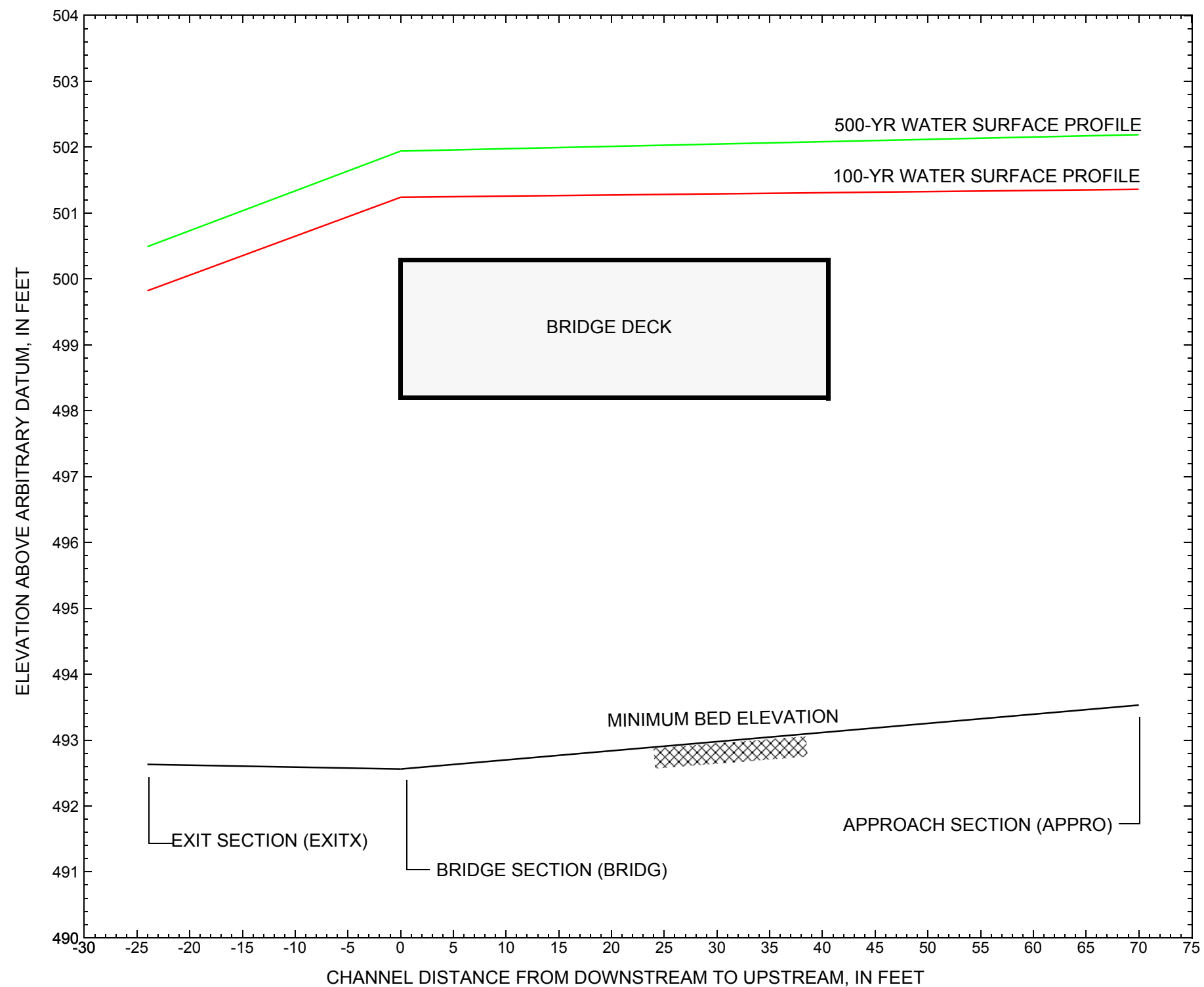

Figure 7. Water-surface profiles for the 100- and 500-yr discharges at structure BENNCYPARK0002 on Park Street, crossing Furnace Brook, Bennington, Vermont. 


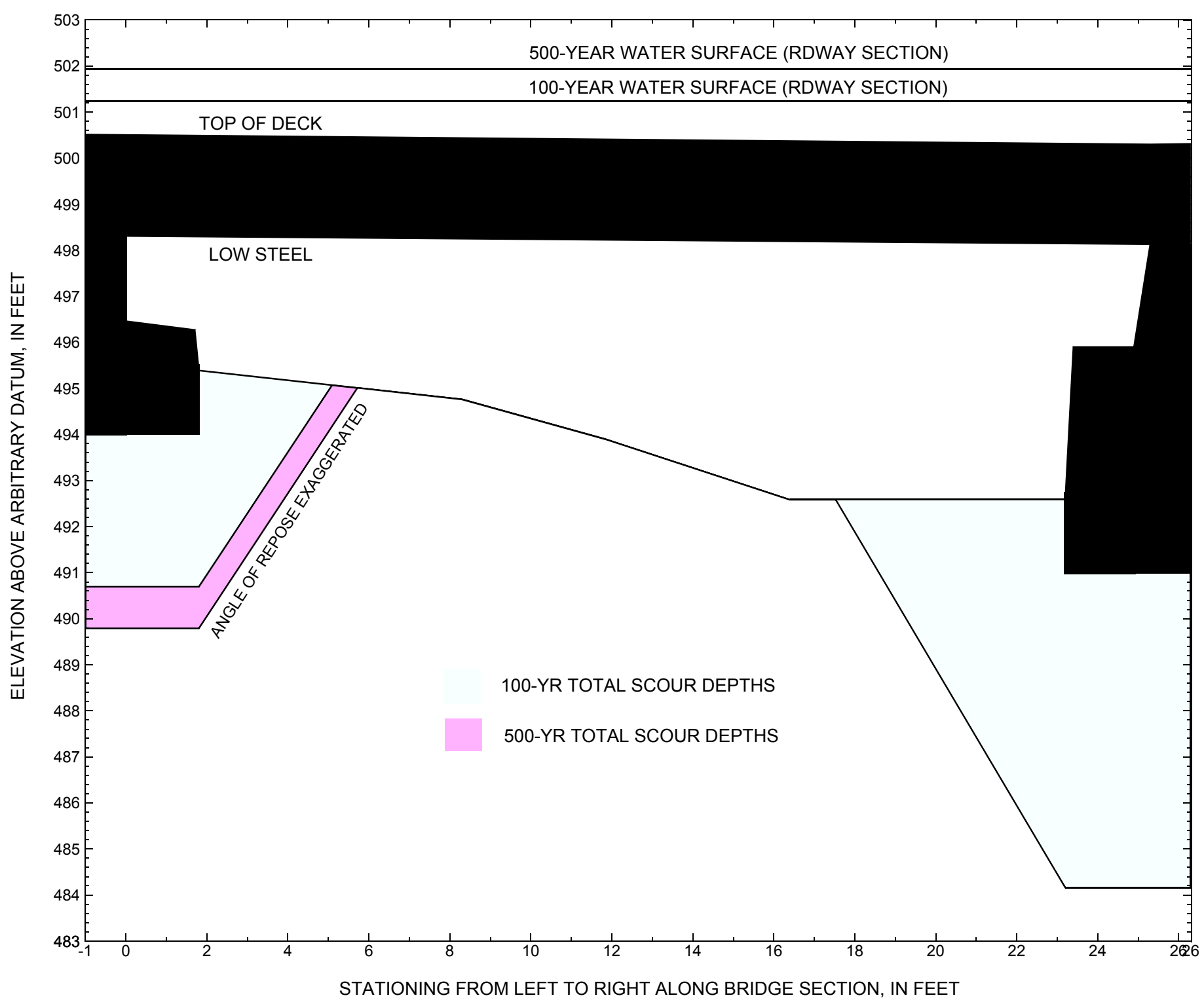

Figure 8. Scour elevations for the 100-yr and 500-yr discharges at structure BENNCYPARK0002 on Park Street, crossing Furnace Brook, Bennington, Vermont. 
Table 1. Remaining footing/pile depth at abutments for the 100-year discharge at structure BENNCYPARK0002 on Park Street, crossing Furnace Brook, Bennington, Vermont.

[VTAOT, Vermont Agency of Transportation; --,no data]

\begin{tabular}{|c|c|c|c|c|c|c|c|c|c|c|c|}
\hline Description & Station $^{1}$ & $\begin{array}{l}\text { VTAOT } \\
\text { minimum } \\
\text { low-chord } \\
\text { elevation } \\
\text { (feet) }\end{array}$ & $\begin{array}{l}\text { Surveyed } \\
\text { minimum } \\
\text { low-chord } \\
\text { elevation }{ }^{2} \\
\text { (feet) }\end{array}$ & $\begin{array}{c}\text { Bottom of } \\
\text { footing } \\
\text { elevation } \\
\text { (feet) }\end{array}$ & $\begin{array}{c}\text { Channel } \\
\text { elevation at } \\
\text { abutment/ } \\
\text { pier }^{2} \\
\text { (feet) }\end{array}$ & $\begin{array}{l}\text { Contraction } \\
\text { scour depth } \\
\text { (feet) }\end{array}$ & $\begin{array}{l}\text { Abutment } \\
\text { scour } \\
\text { depth } \\
\text { (feet) }\end{array}$ & $\begin{array}{l}\text { Pier } \\
\text { scour } \\
\text { depth } \\
\text { (feet) }\end{array}$ & $\begin{array}{l}\text { Depth of } \\
\text { total scour } \\
\text { (feet) }\end{array}$ & $\begin{array}{c}\text { Elevation of } \\
\text { scour }^{2} \\
\text { (feet) }\end{array}$ & $\begin{array}{c}\text { Remaining } \\
\text { footing/pile } \\
\text { depth } \\
\text { (feet) }\end{array}$ \\
\hline \multicolumn{12}{|c|}{100 -yr. discharge is 2,760 cubic-feet per second } \\
\hline Left abutment & 0.0 & 998.4 & 498.3 & 494 & 495.4 & 0.0 & 4.7 & -- & 4.7 & 490.7 & -3 \\
\hline Right abutment & 25.3 & 998.3 & 498.1 & 491 & 492.6 & 0.0 & 8.4 & -- & 8.4 & 484.2 & -7 \\
\hline
\end{tabular}

1.Measured along the face of the most constricting side of the bridge.

2.Arbitrary datum for this study.

Table 2. Remaining footing/pile depth at abutments for the 500-year discharge at structure BENNCYPARK0002 on Park Street, crossing Furnace Brook, Bennington, Vermont.

[VTAOT, Vermont Agency of Transportation; --, no data]

\begin{tabular}{|c|c|c|c|c|c|c|c|c|c|c|c|}
\hline Description & Station $^{1}$ & $\begin{array}{l}\text { VTAOT } \\
\text { minimum } \\
\text { low-chord } \\
\text { elevation } \\
\text { (feet) }\end{array}$ & $\begin{array}{c}\text { Surveyed } \\
\text { minimum } \\
\text { low-chord } \\
\text { elevation }{ }^{2} \\
\text { (feet) }\end{array}$ & $\begin{array}{c}\text { Bottom of } \\
\text { footing } \\
\text { elevation } \\
\text { (feet) }\end{array}$ & $\begin{array}{c}\text { Channel } \\
\text { elevation at } \\
\text { abutment/ } \\
\text { pier }^{2} \\
\text { (feet) }\end{array}$ & $\begin{array}{l}\text { Contraction } \\
\text { scour depth } \\
\text { (feet) }\end{array}$ & $\begin{array}{l}\text { Abutment } \\
\text { scour } \\
\text { depth } \\
\text { (feet) }\end{array}$ & $\begin{array}{l}\text { Pier } \\
\text { scour } \\
\text { depth } \\
\text { (feet) }\end{array}$ & $\begin{array}{l}\text { Depth of } \\
\text { total scour } \\
\text { (feet) }\end{array}$ & $\begin{array}{c}\text { Elevation of } \\
\text { scour }^{2} \\
\text { (feet) }\end{array}$ & $\begin{array}{c}\text { Remaining } \\
\text { footing/pile } \\
\text { depth } \\
\text { (feet) }\end{array}$ \\
\hline \multicolumn{12}{|c|}{500 -yr. discharge is 5,400 cubic-feet per second } \\
\hline Left abutment & 0.0 & 998.4 & 498.3 & 494 & 495.4 & 0.0 & 5.6 & -- & 5.6 & 489.8 & -4 \\
\hline Right abutment & 25.3 & 998.3 & 498.1 & 491 & 492.6 & 0.0 & 8.1 & -- & 8.1 & 484.5 & -7 \\
\hline
\end{tabular}

1.Measured along the face of the most constricting side of the bridge.

2.Arbitrary datum for this study. 


\section{SELECTED REFERENCES}

Arcement, G.J., Jr., and Schneider, V.R., 1989, Guide for selecting Manning's roughness coefficients for natural channels and flood plains: U.S. Geological Survey Water-Supply Paper 2339, 38 p.

Barnes, H.H., Jr., 1967, Roughness characteristics of natural channels: U.S. Geological Survey Water-Supply Paper 1849,213 p.

Benson, M. A., 1962, Factors Influencing the Occurrence of Floods in a Humid Region of Diverse Terrain: U.S. Geological Survey WaterSupply Paper 1580-B, 64 p.

Brown, S.A. and Clyde, E.S., 1989, Design of riprap revetment: Federal Highway Administration Hydraulic Engineering Circular No. 11, Publication FHWA-IP-89-016, 156 p.

Federal Highway Administration, 1983, Runoff estimates for small watersheds and development of sound design: Federal Highway Administration Report FHWA-RD-77-158

Federal Emergency Management Agency, 1986, Flood Insurance Study, Town of Bennington, Bennington County, Vermont: Washington, D.C., June 17, 1986.

Froehlich, D.C., 1989, Local scour at bridge abutments in Ports, M.A., ed., Hydraulic Engineering--Proceedings of the 1989 National Conference on Hydraulic Engineering: New York, American Society of Civil Engineers, p. 13-18.

Hayes, D.C.,1993, Site selection and collection of bridge-scour data in Delaware, Maryland, and Virginia: U.S. Geological Survey WaterResources Investigation Report 93-4017, 23 p.

Interagency Advisory Committee on Water Data, 1982, Guidelines for determining flood flow frequency: U.S. Geological Survey, Bulletin 17B of the Hydrology Subcommittee, 190 p.

Johnson, C.G. and Tasker, G.D.,1974, Progress report on flood magnitude and frequency of Vermont streams: U.S. Geological Survey OpenFile Report 74-130, 37 p.

Lagasse, P.F., Schall, J.D., Johnson, F., Richardson, E.V., Chang, F., 1995, Stream Stability at Highway Structures: Federal Highway Administration Hydraulic Engineering Circular No. 20, Publication FHWA-IP-90-014, 144 p.

Laursen, E.M., 1960, Scour at bridge crossings: Journal of the Hydraulics Division, American Society of Civil Engineers, v. 86, no. HY2, p. 39-53.

Potter, W. D., 1957a, Peak rates of runoff in the Adirondack, White Mountains, and Maine woods area, Bureau of Public Roads

Potter, W. D., 1957b, Peak rates of runoff in the New England Hill and Lowland area, Bureau of Public Roads

Richardson, E.V. and Davis, S.R., 1995, Evaluating scour at bridges: Federal Highway Administration Hydraulic Engineering Circular No. 18, Publication FHWA-IP-90-017, 204 p.

Richardson, E.V., Simons, D.B., and Julien, P.Y., 1990, Highways in the river environment: Federal Highway Administration Publication FHWA-HI-90-016.

Ritter, D.F., 1984, Process Geomorphology: W.C. Brown Co., Debuque, Iowa, 603 p.

Shearman, J.O., 1990, User's manual for WSPRO--a computer model for water surface profile computations: Federal Highway Administration Publication FHWA-IP-89-027, 187 p.

Shearman, J.O., Kirby, W.H., Schneider, V.R., and Flippo, H.N., 1986, Bridge waterways analysis model; research report: Federal Highway Administration Publication FHWA-RD-86-108, 112 p.

Talbot, A.N., 1887, The determination of water-way for bridges and culverts.

U.S. Department of Transportation, 1993, Stream stability and scour at highway bridges, Participant Workbook: Federal Highway Administration Publication FHWA HI-91-011.

U.S. Geological Survey, 1954, Bennington, Vermont 7.5 Minute Series quadrangle map: U.S. Geological Survey Topographic Maps, Scale $1: 24,000$. 


\section{APPENDIX A: \\ WSPRO INPUT FILE}




\section{WSPRO INPUT FILE}

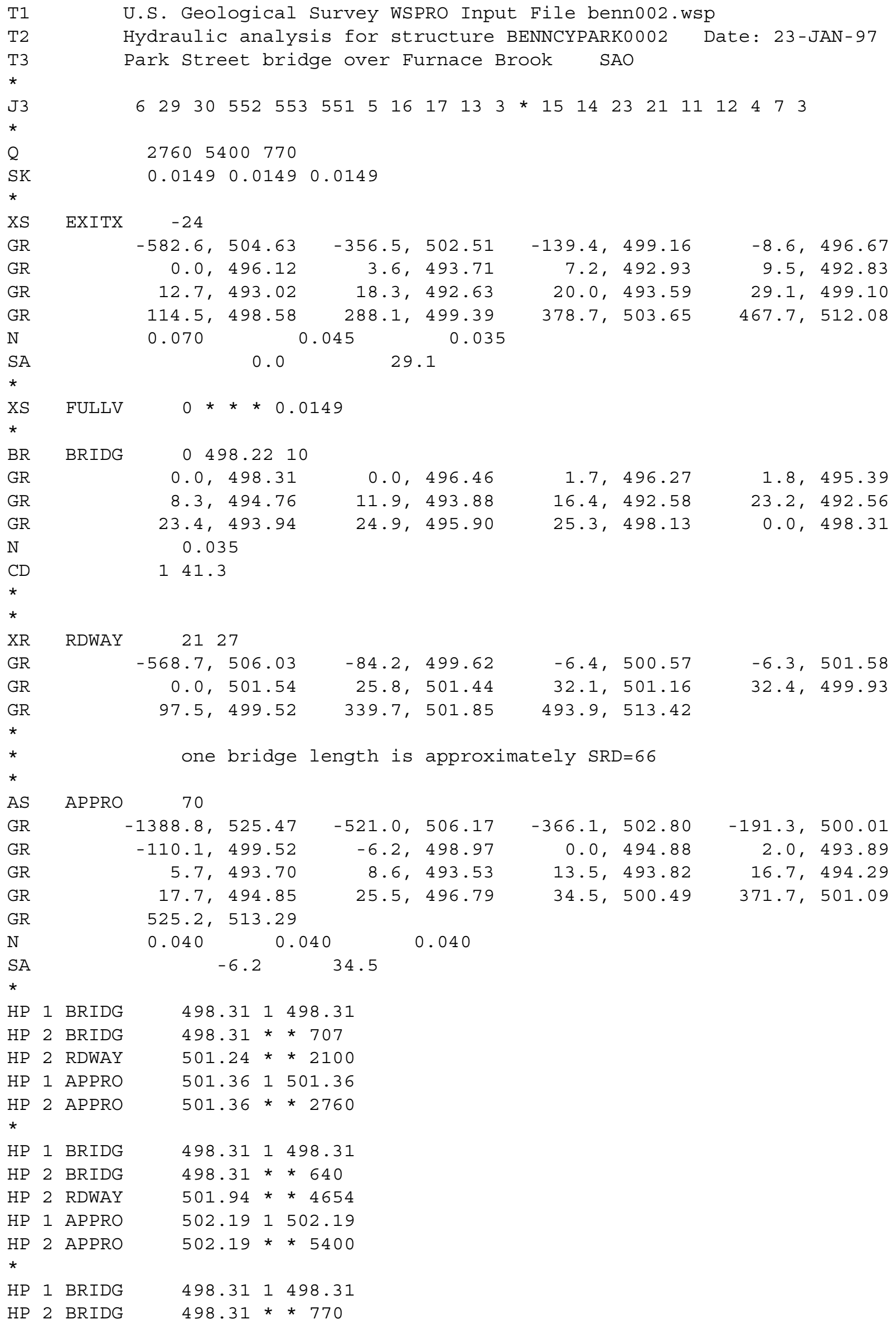




\section{APPENDIX B: \\ WSPRO OUTPUT FILE}




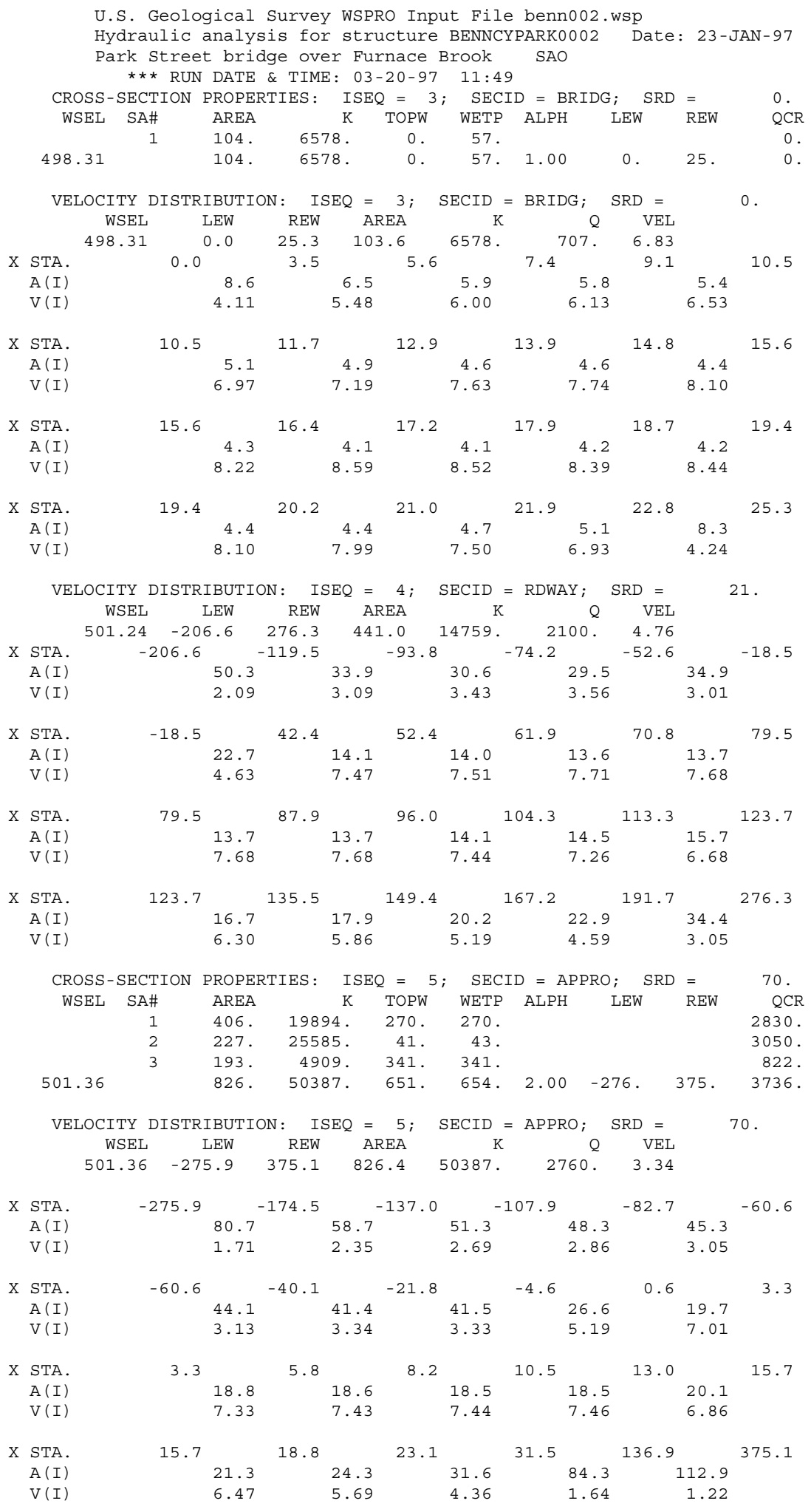


WSPRO OUTPUT FILE (continued)

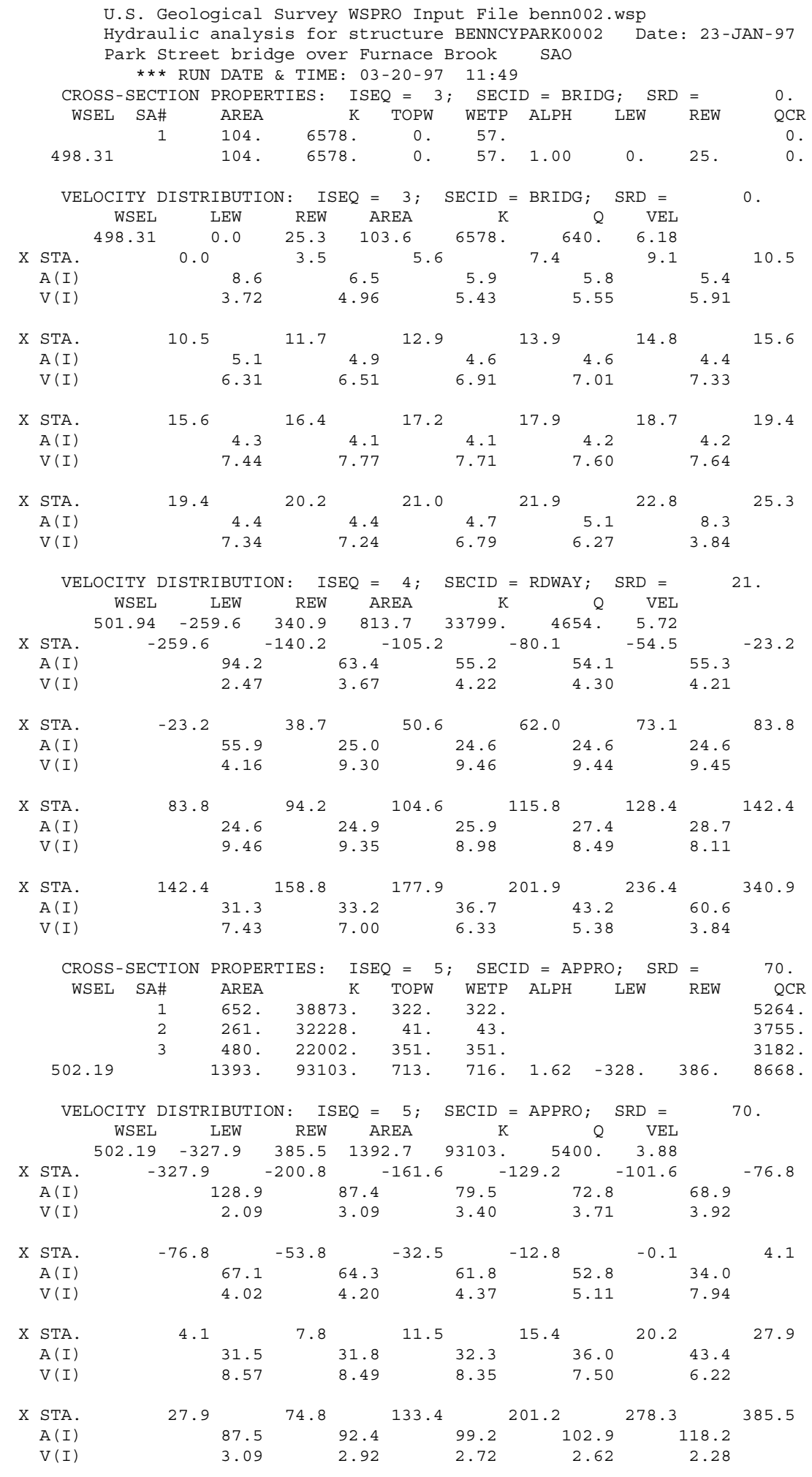


WSPRO OUTPUT FILE (continued)

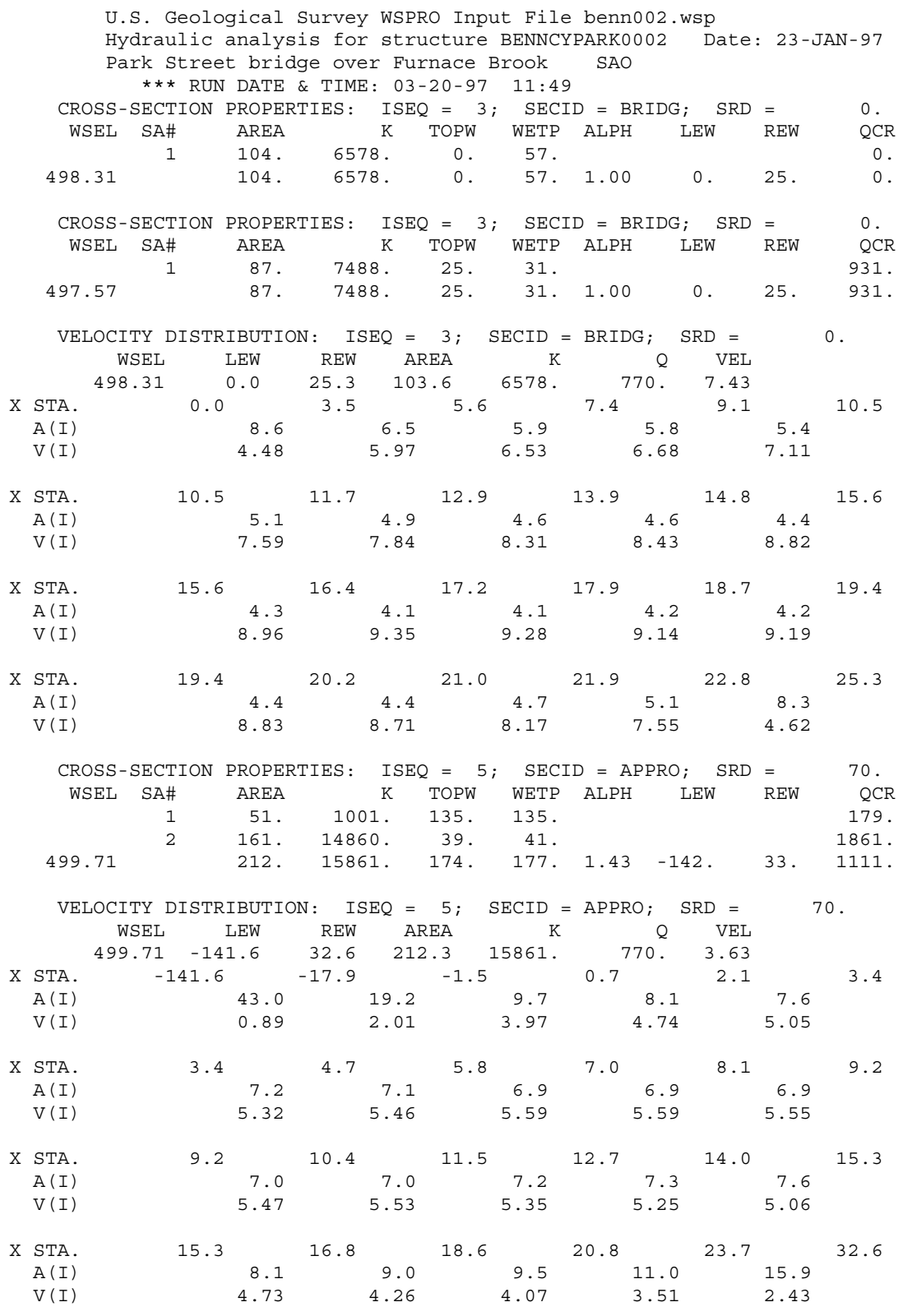


WSPRO OUTPUT FILE (continued)

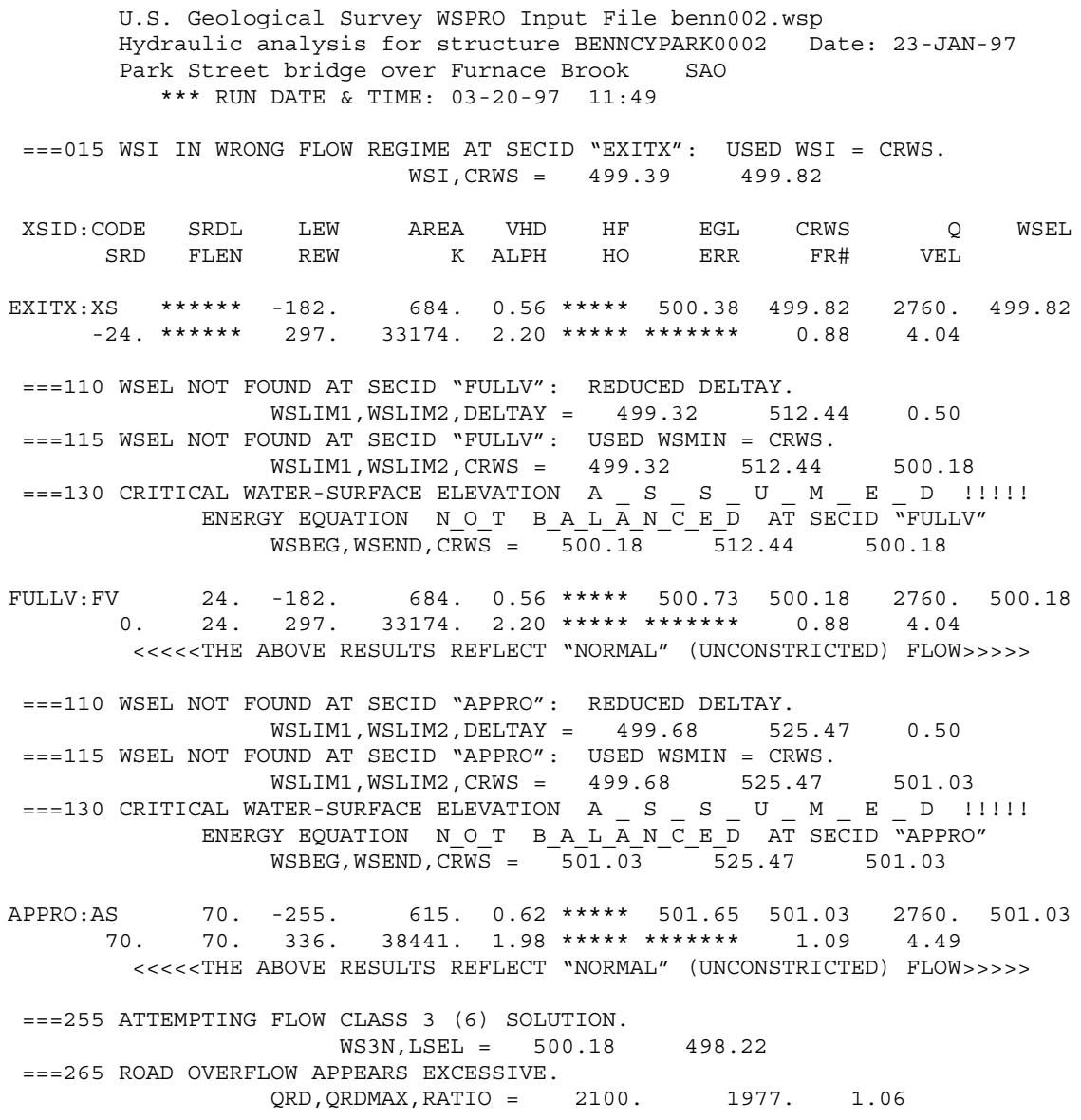


WSPRO OUTPUT FILE (continued)

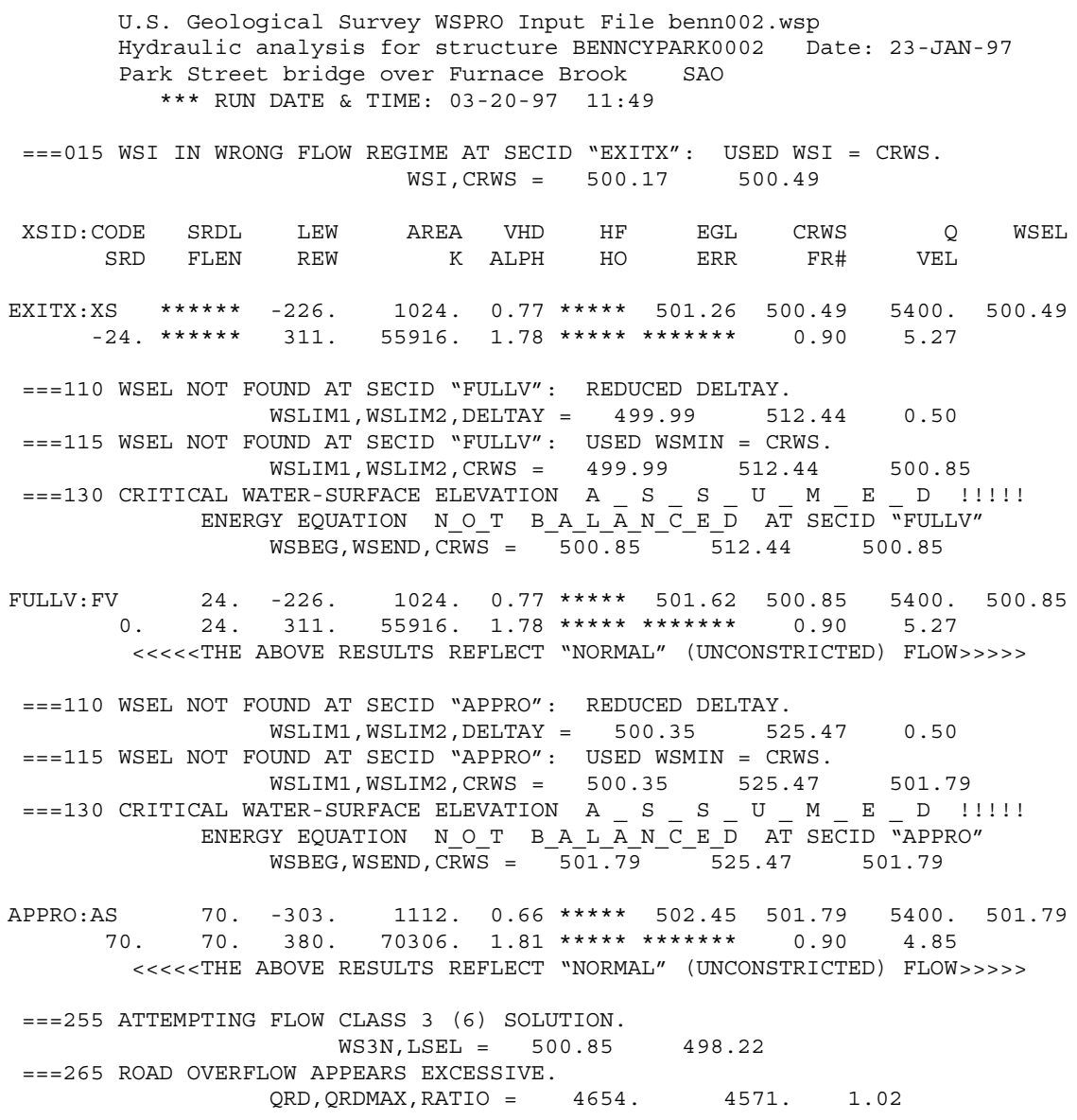


WSPRO OUTPUT FILE (continued)

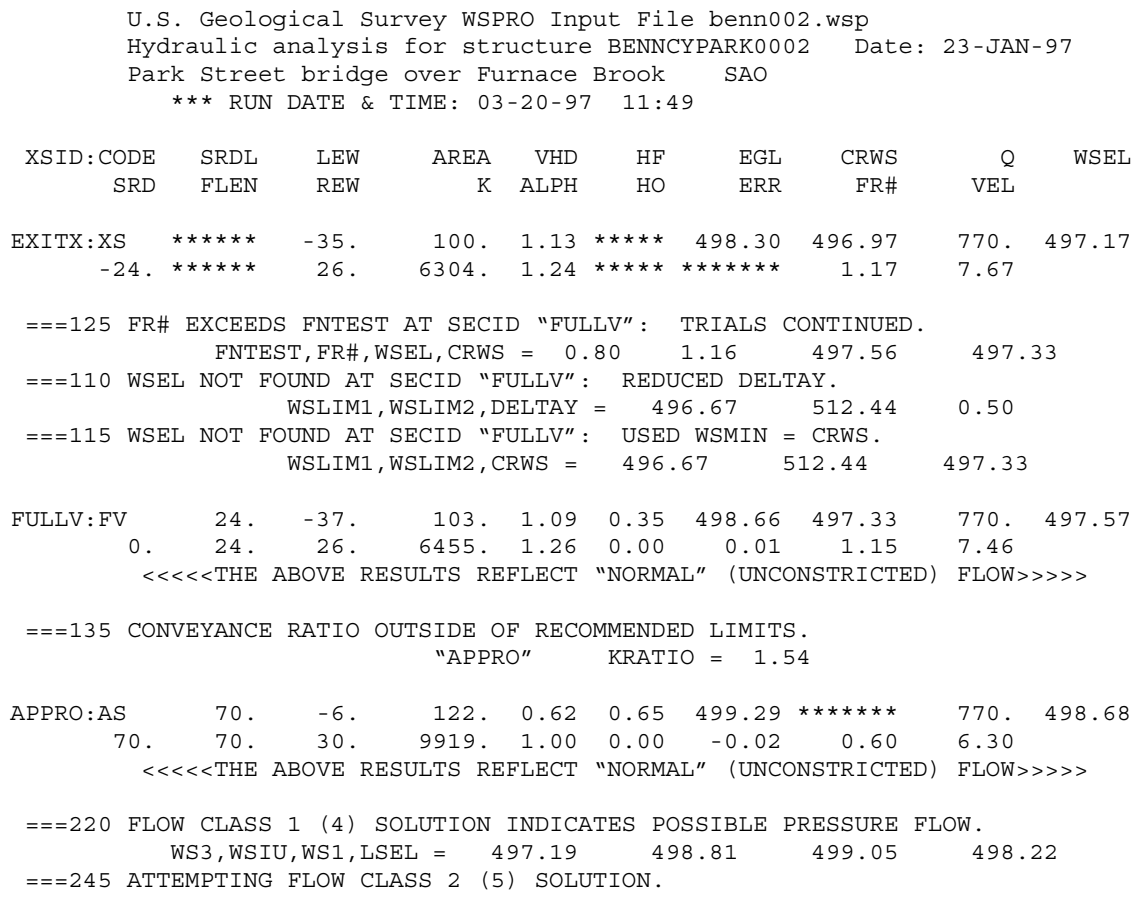




\section{APPENDIX C:}

\section{BED-MATERIAL PARTICAL-SIZE DISTRIBUTION}




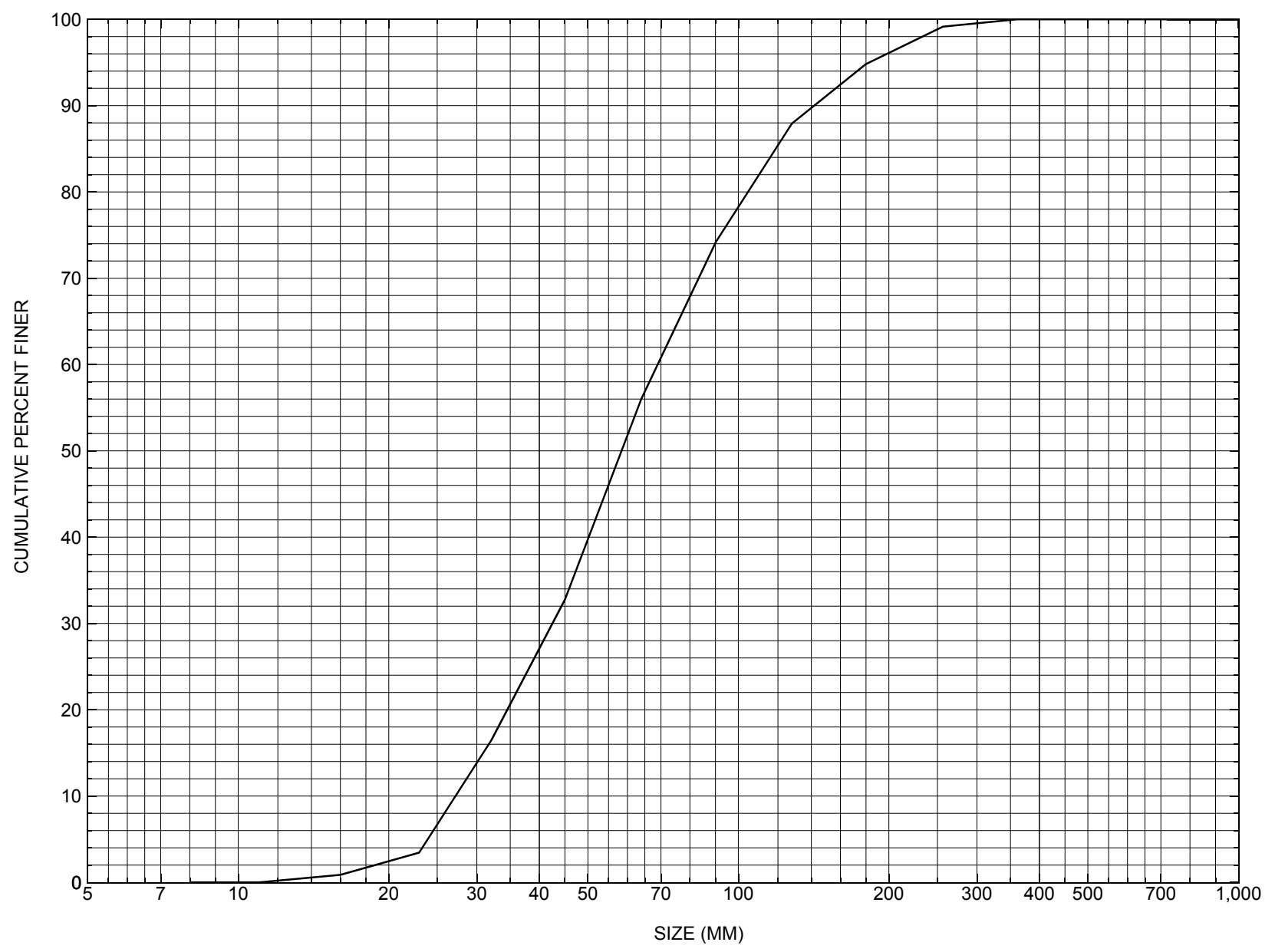

Appendix C. Bed material particle-size distribution for a pebble count in the channel approach of structure BENNCYPARK0002, in Bennington, Vermont. 


\section{APPENDIX D: \\ HISTORICAL DATA FORM}




\section{Structure Number BENNCYPARK0002}

\section{General Location Descriptive}

Data collected by (First Initial, Full last name) $\underline{\mathbf{L}}$. Medalie

Date $(M M / D D / Y Y)+12 / 14 / \underline{95}$

Highway District Number $(I-2 ; n n) \underline{01}$

Town (FIPS place code; I - 4; nnnnn) $\mathbf{0 4 8 2 5}$

Waterway (I - 6) FURNACE BROOK

Route Number -

Topographic Map Bennington

Latitude (I - 16; nnnn.n) $\mathbf{4 2 5 3 6}$
County (FIPS county code; I - 3; nnn)

Mile marker (I - 11; nnn.nnn) $\underline{\mathbf{0 0 0 6 6 0}}$

Road Name (I - 7): PARK STREET

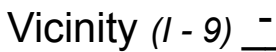

Hydrologic Unit Code: $\mathbf{2 0 2 0 0 0 3}$

Longitude (i - 17; nnnnn.n) 73115

\section{Select Federal Inventory Codes}

FHWA Structure Number (I - 8) $\mathbf{2 0 1 0 3 8 0 0 0 2 0 2 0 2}$

Maintenance responsibility $(I-21 ; n n) \quad 04$

Year built (I - 27; YYYY) 1960

Average daily traffic, ADT (I - 29; nnnnnn) 008300

Year of ADT (I - 30; YY) $\mathbf{9 4}$

Opening skew to Roadway $(I-34 ; n n) \quad 10$

Operational status $(I-41 ; X) \quad \mathbf{A}$

Structure type (I - 43; nnn) 104

Approach span structure type (I - 44; nnn) $\mathbf{0 0 0}$

Number of spans (I - 45; nnn) $\mathbf{0 0 1}$

Number of approach spans (I - 46; nnnn) $\mathbf{0 0 0 0}$

Comments:

*No info on vertical clearance or opening area. According to the structural inspection report dated 6/1/94, this structure is a single span concrete T-beam bridge. The widened portions of the abutments are in good condition, with only minor cracking and scaling. The original portions of the abutments have areas of staining and scaling. There is one full depth crack in the LAB toward the right end of the original portion. Both abutments have a concrete facing near the flow line. The channel takes a moderate turn into the structure. Flow is currently toward the right side of the channel, where there is some scour along the RAB facing, though no undermining noted. There is a sand build up along the LAB side of the channel. 


\section{Bridge Hydrologic Data}

Is there hydrologic data available? $\underline{\mathbf{N}}$ if No, type ctrl-n $h \quad$ VTAOT Drainage area $\left(\mathrm{mi}^{2}\right)^{2}$ :

Terrain character:

Stream character \& type:

Streambed material:

Discharge Data (cfs):

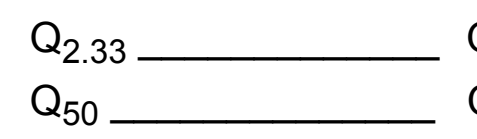

$Q_{10}$ $\mathrm{Q}_{100}$
$Q_{25}$

$Q_{500}$

Record flood date ( $M M / D D / Y Y$ ):

Estimated Discharge (cfs): Velocity at $Q$

Water surface elevation (ft):

Ice conditions (Heavy, Moderate, Light) : (ft/s):

Debris (Heavy, Moderate, Light):

The stage increases to maximum highwater elevation (Rapidly, Not rapidly):

The stream response is (Flashy, Not flashy):

Describe any significant site conditions upstream or downstream that may influence the stream's stage:

Watershed storage area (in percent): $\%$

The watershed storage area is: (1-mainly at the headwaters; 2- uniformly distributed; 3-immediatly upstream oi the site)

Water Surface Elevation Estimates for Existing Structure:

\begin{tabular}{|l|l|l|l|l|l|}
\hline $\begin{array}{l}\text { Peak discharge frequency } \\
\text { Water surface elevation (ft) } \\
\text { Velocity }(\mathrm{ft} / \mathrm{sec})\end{array}$ & $\mathrm{Q}_{2.33}$ & $\mathrm{Q}_{10}$ & $\mathrm{Q}_{25}$ & $\mathrm{Q}_{50}$ & $\mathrm{Q}_{100}$ \\
\hline
\end{tabular}

Long term stream bed changes:

Is the roadway overtopped below the $\mathrm{Q}_{100}$ ? (Yes, No, Unknown):

Frequency:

Relief Elevation (ft):

Discharge over roadway at $Q_{100}\left(f t^{3} / \mathrm{sec}\right)$ :

Are there other structures nearby? (Yes, No, Unknown): Upstream distance (miles): Town: If No or Unknown, type ctrl-n os

Highway No. : Structure No. : Year Built:

Clear span (ft): Clear Height (ft): Structure Type: Full Waterway $\left(t^{2}\right)$ : 
Downstream distance (miles): Town: Year Built:

Highway No. : Structure No. : Structure Type:

Clear span (ft): Clear Height (ft): Full Waterway $\left(f^{2}\right)$ :

Comments:

\section{USGS Watershed Data}

Watershed Hydrographic Data

Drainage area (DA) 12.76

Watershed storage (ST)

Bridge site elevation

Main channel length

649

8.53

$10 \%$ channel length elevation $\mathrm{mi}^{2}$ 0 649 $\mathrm{ft}$ $\mathrm{mi}$

Main channel slope

(S) 47.68 720 $\mathrm{ft} \quad 85 \%$ channel length elevation $\mathrm{ft}$
Lake and pond area $\underline{\mathbf{0 . 0 0 1}} \mathrm{mi}^{2}$

Headwater elevation $\mathbf{3 4 1 8} \mathrm{ft}$

Watershed Precipitation Data

Average site precipitation in Average headwater precipitation in

Maximum 2yr-24hr precipitation event $(124,2)$ in

Average seasonal snowfall (Sn) $\mathrm{ft}$ 


\section{Bridge Plan Data}

Are plans available? $\mathbf{Y}$ If no, type ctrl-n pl

Project Number SA $\mathbf{4 2} 1958$

Minimum channel bed elevation:

Low superstructure elevation: USLAB $\mathbf{9 9 8 . 3 7}$

DSLAB 998.37

USRAB 998.07

DSRAB 998.28

Benchmark location description:

NO BENCHMARK INFORMATION

Reference Point (MSL, Arbitrary, Other): Arbitrary Datum (NAD27, NAD83, Other):

Foundation Type: 1

If 1: Footing Thickness $\mathbf{2 . 0} \quad$ Footing bottom elevation: $\underline{\mathbf{9 9 1 . 0}}$

If 2: Pile Type: (1-Wood; 2-Steel or metal; 3-Concrete) Approximate pile driven length:

If 3: Footing bottom elevation:

Is boring information available? $\mathbf{N}$ If no, type ctrl-n bi Number of borings taken: -

Foundation Material Type: $\mathbf{3}$ (1-regolith, 2-bedrock, 3-unknown)

Briefly describe material at foundation bottom elevation or around piles:

NO DRILL BORING INFORMATION

Comments:

Low steel elevation shown is an average overall low steel elevation. Footing bottom elevation for the RAB is 991'; for the LAB is 994'.

The low superstructure elevations are bridge seat elevations. 


\section{Cross-sectional Data}

Is cross-sectional data available? $\underline{\mathbf{Y}}$ If no, type ctrl-n xs

Source (FEMA, VTAOT, Other)? FEMA

Comments:

\begin{tabular}{|c|c|c|c|c|c|c|c|c|c|c|c|}
\hline Station & 1607 & 1612 & 1618 & 1626 & 1630 & - & - & - & - & - & - \\
\hline Feature & LAB & - & - & - & RAB & - & - & - & - & - & - \\
\hline $\begin{array}{l}\text { Low cord } \\
\text { elevation }\end{array}$ & 646.6 & 646.6 & 646.6 & 646.6 & 646.6 & - & - & - & - & - & - \\
\hline $\begin{array}{l}\text { Bed } \\
\text { elevation }\end{array}$ & 641.9 & 640.9 & 640.9 & 641.9 & - & - & - & - & - & - & - \\
\hline $\begin{array}{l}\text { Low cord to } \\
\text { bed length }\end{array}$ & 4.7 & 5.7 & 5.7 & 5.5 & - & - & - & - & - & - & - \\
\hline Station & - & - & - & - & - & - & - & - & - & - & - \\
\hline Feature & - & - & - & - & - & - & - & - & - & - & - \\
\hline $\begin{array}{l}\text { Low cord } \\
\text { elevation }\end{array}$ & - & - & - & - & - & - & - & - & - & - & - \\
\hline $\begin{array}{l}\text { Bed } \\
\text { elevation }\end{array}$ & - & - & - & - & - & - & - & - & - & - & - \\
\hline $\begin{array}{l}\text { Low cord to } \\
\text { bed length }\end{array}$ & - & - & - & - & - & - & - & - & - & - & - \\
\hline
\end{tabular}

Source (FEMA, VTAOT, Other)?

Comments:

\begin{tabular}{|l|l|l|l|l|l|l|l|l|l|l|l|l|}
\hline Station & - & - & - & - & - & - & - & - & - & - \\
\hline Feature & - & - & - & - & - & - & - & - & - & - \\
\hline $\begin{array}{l}\text { Low cord } \\
\text { elevation }\end{array}$ & - & - & - & - & - & - & - & - & - & - & - \\
\hline $\begin{array}{l}\text { Bed } \\
\text { elevation }\end{array}$ & - & - & - & - & - & - & - & - & - & - \\
\hline $\begin{array}{l}\text { Low cord to } \\
\text { bed length }\end{array}$ & - & - & - & - & - & - & - & - & - & - & - \\
\hline \begin{tabular}{l} 
Station \\
\hline \begin{tabular}{l} 
Feature \\
\hline
\end{tabular}
\end{tabular}$-$ & - & - & - & - & - & - & - & - & - & - \\
\hline $\begin{array}{l}\text { Low cord } \\
\text { elevation }\end{array}$ & - & - & - & - & - & - & - & - & - & - \\
\hline $\begin{array}{l}\text { Bed } \\
\text { elevation }\end{array}$ & - & - & - & - & - & - & - & - & - & - \\
\hline $\begin{array}{l}\text { Low cord to } \\
\text { bed length }\end{array}$ & - & - & - & - & - & - & - & - & - & - \\
\hline
\end{tabular}




\section{APPENDIX E: \\ LEVEL I DATA FORM}


U. S. Geological Survey

Bridge Field Data Collection and Processing Form

Qa/Qc Check by: RB Date: $10 / 7 / 96$

\section{Structure Number}

BENNCYPARKO002

Computerized by: $\underline{\mathbf{R B}}$ Date: $10 / 8 / 96$

Reviewd by: SAO Date: $\underline{\mathbf{4} / \mathbf{2} / 97}$

\section{A. General Location Descriptive}

1. Data collected by (First Initial, Full last name) E. BOEHMLER

Date $(M M / D D / Y Y) \underline{08} / \underline{06} / \underline{1996}$

2. Highway District Number $\mathbf{0 1}$

County 003 BENNINGTON

Mile marker 0000

Waterway $(I$ - 6) FURNACE BROOK

Town 04825 BENNINGTON

Road Name PARK STREET

Route Number -

Hydrologic Unit Code: 2020003

3. Descriptive comments:

Located at the intersection of Park Street and North Branch Extension.

\section{B. Bridge Deck Observations}
4. Surface cover... LBUS 5
RBUS 4
LBDS 4
RBDS 4
Overall 4

(2b us, ds,lb,rb: 1- Urban; 2- Suburban; 3- Row crops; 4- Pasture; 5- Shrub- and brushland; 6- Forest; 7- Wetland)
5. Ambient water surface... US 1
UB 2
DS 1
(1- pool; 2- riffle)

6. Bridge structure type 1 (1- single span; 2- multiple span; 3- single arch; 4- multiple arch; 5-cylindrical culvert; 6- box culvert; or 7- other)
7. Bridge length 29
(feet)
Span length $\mathbf{2 6}$
(feet)
Bridge width 27 (feet)

\section{Road approach to bridge:}
8. LB 0 RB 0
( 0 even, 1- lower, 2- higher)
9. LB
RB 1
(1- Paved, 2- Not paved)

10. Embankment slope (run / rise in feet / foot)

US left

US right

\begin{tabular}{|c|c|c|c|}
\hline \multicolumn{2}{|c|}{ Protection } & \multirow{2}{*}{ 13.Erosion } & 14.Severity \\
\hline 11.Type & 12.Cond. & $\mathbf{0}$ & $\mathbf{0}$ \\
\hline $\mathbf{2}$ & $\mathbf{1}$ & $\mathbf{0}$ & $\mathbf{0}$ \\
\hline $\mathbf{1}$ & $\mathbf{1}$ & $\mathbf{0}$ & $\mathbf{0}$ \\
$\mathbf{2}$ & $\mathbf{1}$ & $\mathbf{1}$ \\
\hline $\mathbf{0}$ & $\mathbf{0}$ & $\mathbf{0}$ & $\mathbf{0}$ \\
\hline
\end{tabular}

Bank protection types: 0- none; 1- < 12 inches;

2- $<36$ inches; $3-<48$ inches

4- < 60 inches; 5- wall / artificial levee

Bank protection conditions: 1- good; 2- slumped;

3- eroded; 4- failed

Erosion: 0 - none; 1- channel erosion; 2 -

road wash; 3- both; 4- other

Erosion Severity: 0 - none; 1- slight; 2- moderate; 3- severe

Channel approach to bridge (BF):

15. Angle of approach: $\underline{\mathbf{3 0}}$

16. Bridge skew: 45

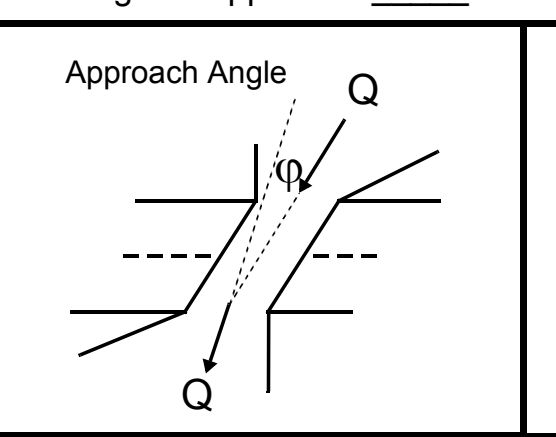

17. Channel impact zone 1:

Where? RB (LB, RB)

Exist? $\mathbf{Y}(Y$ or $N)$

Bridge Skew Angle

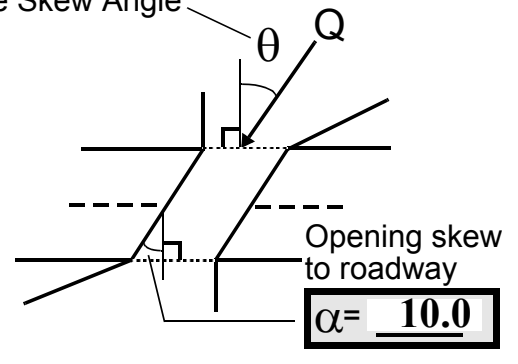

Range? 15

feet US

Severity 3

Channel impact zone 2:

(US, UB, DS) to 15 feet $\underline{\mathbf{U B}}$

Where? RB (LB, RB)

Exist? $\mathbf{Y}(\mathrm{Y}$ or $N)$

Severity $\underline{0}$

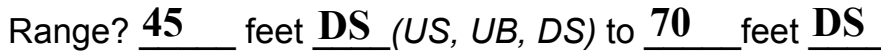

Impact Severity: 0- none to very slight; 1- Slight; 2- Moderate; 3- Severe 
18. Bridge Type: $\mathbf{1 b}$

1a- Vertical abutments with wingwalls

$1 \mathrm{~b}$ - Vertical abutments without wingwalls

2- Vertical abutments and wingwalls, sloping embankment Wingwalls perpendicular to abut. face

3- Spill through abutments

4- Sloping embankment, vertical wingwalls and abutments

Wingwall angle less than $90^{\circ}$.

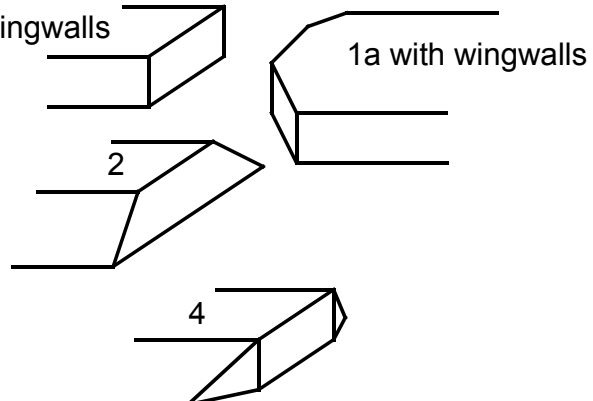

19. Bridge Deck Comments (surface cover variations, measured bridge and span lengths, bridge type variations, approach overflow width, etc.)

7. Values are from the VT AOT files. Measured bridge length is $30 \mathrm{ft}$., bridge width is $\mathbf{2 7}$, and clear span length is $27 \mathrm{ft}$. (at the DS face).

4. The North Branch Extension roadway runs along the US and DS right bank.

The US bridge face is curved with the US most concrete beam support in the shape of a "Y".

\section{Upstream Channel Assessment}

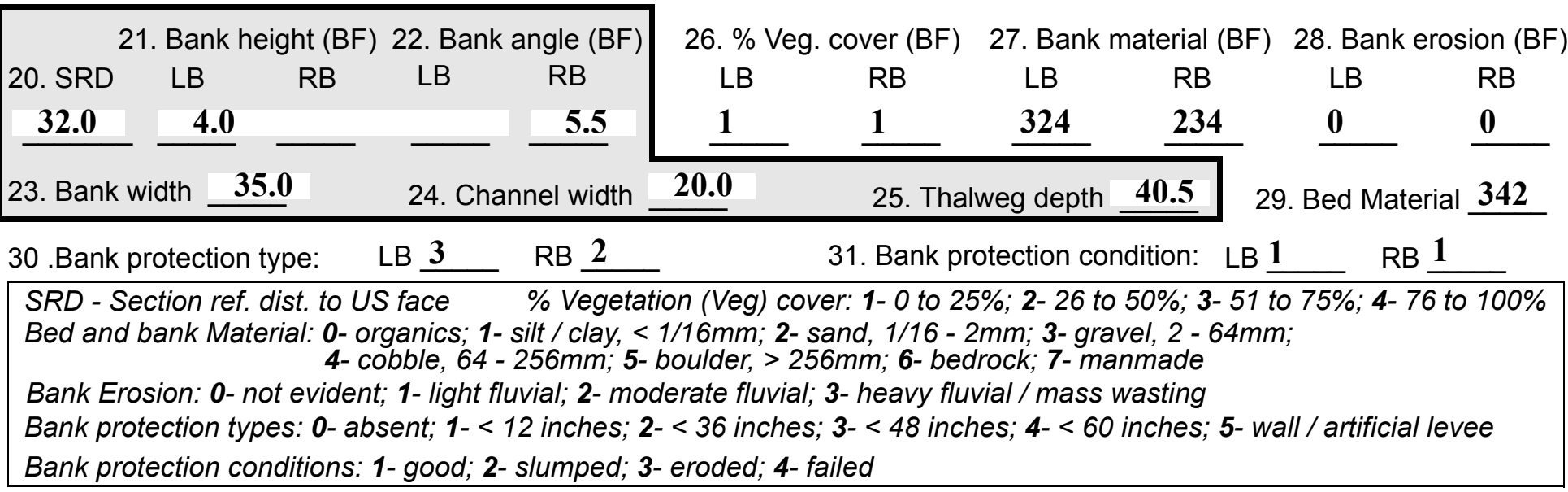

32. Comments (bank material variation, minor inflows, protection extent, etc.):

30. Both banks are protected with some placed channel material and fill of cobbles and boulders. The left bank side has at least 5 slabs of concrete laid on the cobble and boulder material and angled in toward the center of the channel. Bank protection extends from the bridge face to $95 \mathrm{ft}$. US.

27. Bank material assessment was made US of $100 \mathrm{ft}$. US.

There is a pooled area of the channel in the US reach between 2 riffle zones all within $100 \mathrm{ft}$. of the bridge. The gradient is moderate. 
33.Point/Side bar present? $\mathbf{N}$

(Y or $N$. if $N$ type ctrl-n pb)34. Mid-bar distance-

35. Mid-bar width: -

36. Point bar extent: feet -

(US, UB) to feet -

(US, UB, DS) positioned -

$\%$ LB to $\%$ RB

37. Material: -

38. Point or side bar comments (Circle Point or Side; Note additional bars, material variation, status, etc.):

NO POINT BARS

39. Is a cut-bank present? $\mathbf{N}$ (Y or if $N$ type ctrl-n cb)

40. Where? -

(LB or $R B)$

41. Mid-bank distance: -

42. Cut bank extent: - feet -

(US, UB) to feet (US, UB, DS)

43. Bank damage: -

(1- eroded and/or creep; 2- slip failure; 3- block failure)

44. Cut bank comments (eg. additional cut banks, protection condition, etc.):

NO CUT BANKS

\section{Is channel scour present? $\mathbf{Y}$ ( $Y$ or if $N$ type ctrl-n cs)}

46. Mid-scour distance: $\mathbf{5 0}$

47. Scour dimensions: Length $\mathbf{3 5}$ Width 7 Depth : 1

Position 10

$\%$ LB to 65

$\% \mathrm{RB}$

48. Scour comments (eg. additional scour areas, local scouring process, etc.):

The concrete slabs on the left bank and the stone fill on the right bank constrict the channel in the region of 30

ft. US to $65 \mathrm{ft}$. US and the channel responds with localized bed scouring.

\section{Are there major confluences? $\mathbf{Y}$}

51. Confluence 1: Distance 100

Confluence 2: Distance -
(Y or if $N$ type ctrl-n mc)

52. Enters on $\underline{\mathbf{L B}}$ (LB or RB)

Enters on ( $L B$ or $R B)$

54. Confluence comments (eg. confluence name):

This confluence has no name and is very small.

\section{Under Bridge Channel Assessment}

55. Channel restraint (BF)? LB 2

\begin{tabular}{|ccccc}
\hline \multicolumn{2}{|c|}{ 56. Height (BF) } & \multicolumn{2}{c}{57 Angle (BF) } \\
LB & RB & LB & RB \\
$\mathbf{1 7 . 5}$ & & & $\mathbf{1 . 5}$ & \\
\hline
\end{tabular}

53. Type 1 (1-perennial; 2- ephemeral)

Type (1-perennial; 2- ephemeral)

\section{... ___ (1- natural bank; 2- abutment; 3- artificial levee)}

58. Bank width (BF) -

59. Channel width $(\mathrm{Amb})$

61. Material (BF)

LB $\quad$ RB

$\underline{2} \quad \underline{7}$
62. Erosion (BF)

LB RB

$7 \quad 0$
63. Bed Material $\mathbf{0}$

Bed and bank Material: 0- organics; 1- silt / clay, < 1/16mm; 2- sand, 1/16 - 2mm; 3- gravel, 2 - 64mm; 4- cobble, 64 - 256mm; 5- boulder, > 256mm; 6- bedrock; 7- manmade

Bank Erosion: 0- not evident; 1- light fluvial; 2- moderate fluvial; 3- heavy fluvial / mass wasting

64. Comments (bank material variation, minor inflows, protection extent, etc.):

342

The stream bed under the bridge drops at least $2 \mathrm{ft}$. in elevation between the US face and $8 \mathrm{ft}$. under the bridge. The flow shifts from covering the entire bed to only $25 \%$ of the bed under the bridge. A large bar has developed along the left abutment and the main channel flow is along the right abutment. The channel deepens from $0.5 \mathrm{ft}$. at the US face to $2 \mathrm{ft}$. deep at $8 \mathrm{ft}$. under the bridge from the US bridge face, and remains at this depth the remaining width of the bridge. The point bar extends from $4 \mathrm{ft}$. under the bridge to $0 \mathrm{ft}$. DS. It is positioned from $0 \% \mathrm{LB}$ to $75 \% \mathrm{RB}$ and is composed of mainly gravel with coarse sand and cobbles. The material coarsens toward the right abutment. The bar is $13 \mathrm{ft}$. wide at $16 \mathrm{ft}$. under the bridge from the DS 
65. Debris and Ice Is there debris accumulation? bri (Y or $N)$ 66. Where? dge (1- Upstream; 2- At bridge; 3- Both)

67. Debris Potential fac (1-Low; 2- Moderate; 3- High) 68. Capture Efficiency (1- Low; 2- Moderate; 3- High)

69. Is there evidence of ice build-up? $\mathbf{N}(Y$ or $N)$ Ice Blockage Potential (1- Low; 2- Moderate; 3- High)

70. Debris and Ice Comments:

2

2

$\mathbf{N}$

2

Ice and debris will likely get hung up on the bar under the bridge. Low chord is very low with only about 4

\begin{tabular}{|c|c|c|c|c|c|c|c|c|}
\hline Abutments & $\begin{array}{l}\text { 71. Attack } \\
\angle(\mathrm{BF})\end{array}$ & $\begin{array}{l}\text { 72. Slope } \angle \\
(\text { Qmax })\end{array}$ & $\begin{array}{l}\text { 73. Toe } \\
\text { loc. (BF) }\end{array}$ & $\begin{array}{l}\text { 74. Scour } \\
\text { Condition }\end{array}$ & $\begin{array}{l}\text { 75. Scour } \\
\text { depth }\end{array}$ & $\begin{array}{c}\text { 76. Exposure } \\
\text { depth }\end{array}$ & 77. Material & 78. Length \\
\hline LABUT & ft. of & clear & ance & at & the & US & face. & 90.0 \\
\hline RABUT & Ther & e are & trees & & & on & the & 24.0 \\
\hline
\end{tabular}

Pushed: $L B$ or RB

Toe Location (Loc.): 0- even, 1- set back, 2- protrudes

Scour cond.: 0- not evident; 1- evident (comment); 2- footing exposed; 3-undermined footing; 4- piling exposed; 5- settled; 6- failed

Materials: 1- Concrete; 2- Stone masonry or drywall; 3- steel or metal; 4- wood

79. Abutment comments (eg. undermined penetration, unusual scour processes, debris, etc.):

banks US.

90

2

2

0

1.0

80. Wingwalls:

Exist? Material? Scour Scour Exposure Angle? Length? Condition? depth? depth?

USLWW: 1

35

USRWW: 2

$\frac{1}{2}$

DSLWW: 4.5

DSRWW:

e are

$35-90$

24.0

2

90

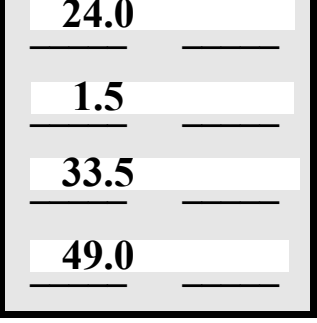

Wingwall materials: 1- Concrete; 2- Stone masonry or drywall; 3- steel or metal; 4- wood

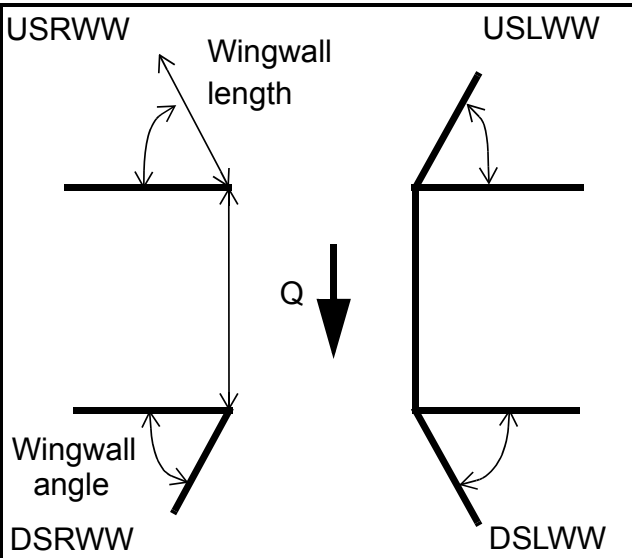

82. Bank / Bridge Protection:

\begin{tabular}{|l|l|l|l|l|l|l|l|l|}
\hline Location & USLWW & USRWW & LABUT & RABUT & LB & RB & DSLWW & DSRWW \\
\hline Type & cret & ngs & left & t & ts. & evi- & alon & righ \\
\hline Condition & e & on & and & abut & Sco & dent & g & t \\
\hline Extent & footi & the & righ & men & uris & only & the & abut \\
\hline
\end{tabular}

Bank / Bridge protection types: 0- absent; 1- < 12 inches; 2- < 36 inches; 3- < 48 inches; 4- < 60 inches; 5- wall / artificial levee

Bank / Bridge protection conditions: 1- good; 2- slumped; 3- eroded; 4- failed

Protection extent: 1- entire base length; 2- US end; 3- DS end; 4- other 
83. Wingwall and protection comments (eg. undermined penetration, unusual scour processes, etc.):

ment and the scour depth ranges from $1 \mathrm{ft}$. to $1.5 \mathrm{ft}$. with an ambient thalweg depth elsewhere of $1 \mathrm{ft}$. The right abutment footing at the US most $8 \mathrm{ft}$. is angled at 35 degrees relative to the rest of the footing. This angled footing is in the direction of flow from the US reach. There is a concrete slab across the bed at the DS face on the right abutment side that appears to be built into the right abutment footing. This slab may impede localized scour.

$\mathbf{N}$

\section{Piers:}

84. Are there piers? _ _ (Y or if $N$ type ctrl-n pr)

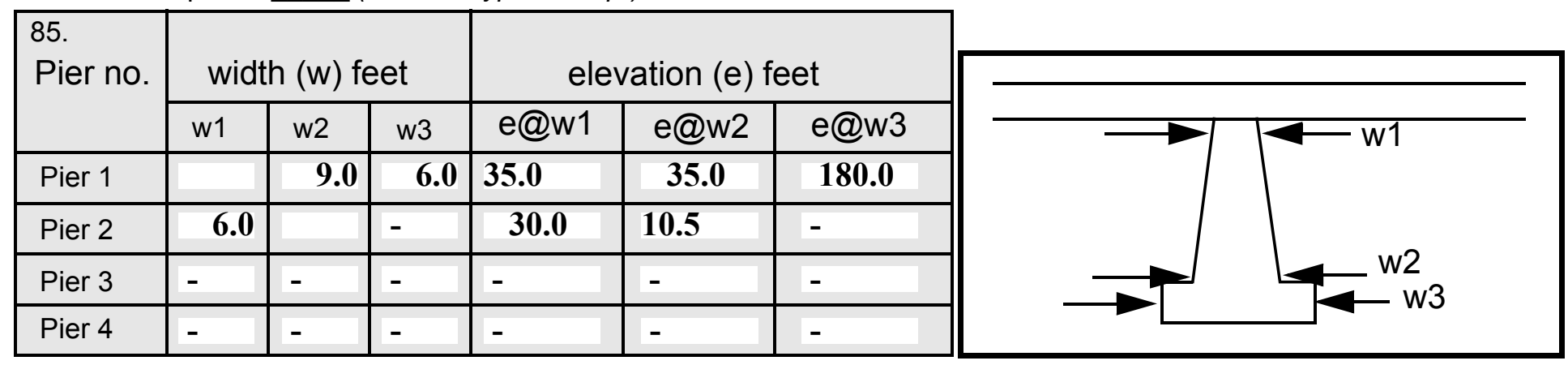

\begin{tabular}{|l|l|l|l|l|}
\hline Level 1 Pier Descr. & \multicolumn{1}{|c|}{1} & \multicolumn{1}{|c|}{2} & \multicolumn{1}{|c|}{4} \\
\hline 86. Location (BF) & - & N & - & - \\
\hline 87. Type & - & - & - & - \\
\hline 88. Material & N & - & $\mathbf{0}$ & $\mathbf{0}$ \\
\hline 89. Shape & - & - & - & - \\
\hline 90. Inclined? & - & - & - & - \\
\hline 91. Attack $\angle$ (BF) & - & $\mathbf{0}$ & - & No \\
\hline 92. Pushed & - & - & - & wing \\
\hline 93. Length (feet) & - & - & - & - \\
\hline 94. \# of piles & $\mathbf{N}$ & - & - & walls \\
\hline 95. Cross-members & - & $\mathbf{0}$ & - & On \\
\hline 96. Scour Condition & - & - & - & the \\
\hline 97. Scour depth & - & - & - & right \\
\hline 98. Exposure depth & - & $\mathbf{0}$ & $\mathbf{0}$ & abut \\
\hline
\end{tabular}

LFP, LTB, LB, MCL, MCM, MCR, RB, RTB, RFP

1- Solid pier, 2-column, 3- bent

1- Wood; 2- concrete; 3- metal; 4- stone

1- Round; 2- Square; 3- Pointed

Y-yes; $N$ - no

$L B$ or $R B$

0- none; 1- laterals; 2- diagonals; 3- both

0- not evident; 1- evident (comment);

2- footing exposed; 3- piling exposed;

4- undermined footing; 5- settled; 6- failed 
99. Pier comments (eg. undermined penetration, protection and protection extent, unusual scour processes, etc.):

ment side where the bridge extension is present, there is type 2 protection around the end of the wall.

100.

\section{E. Downstream Channel Assessment}

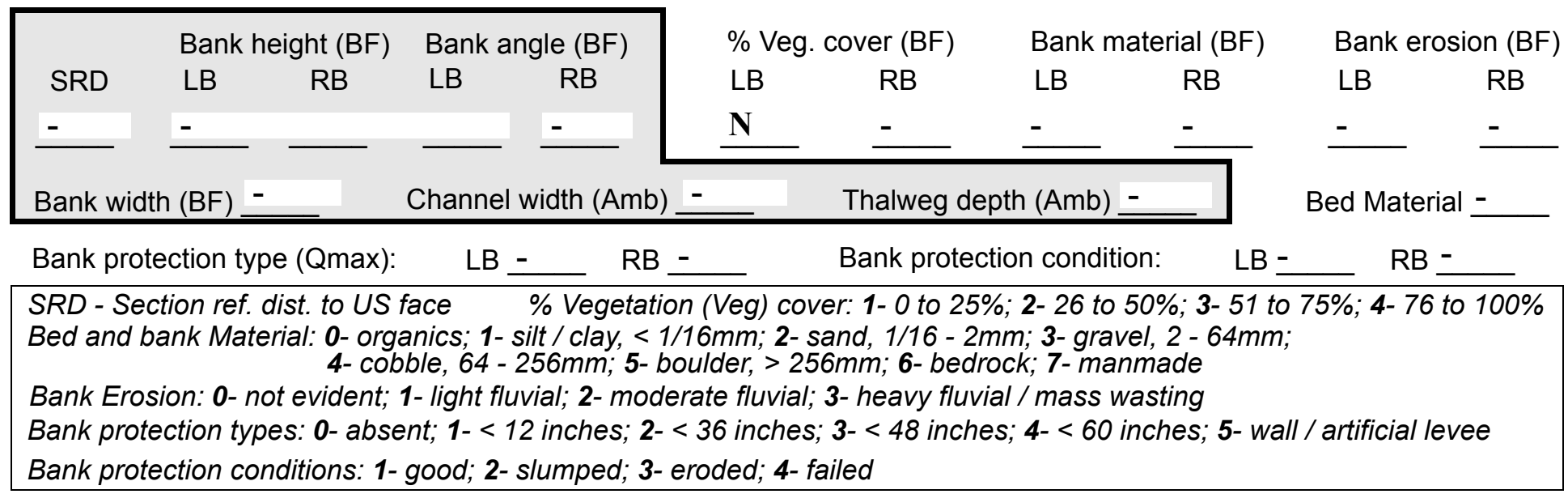

Comments (eg. bank material variation, minor inflows, protection extent, etc.):$$
-
$$$$
-
$$

$-$

$-$

$-$

$-$

$-$

$-$

$-$

$-$

$-$

$-$

$-$

$-$

$-$

\section{Is a drop structure present? __ (Y or N, if $N$ type ctrl-n ds) 102. Distance: ___ feet}

103. Drop: __ feet 104. Structure material: __ (1- steel sheet pile; 2- wood pile; 3- concrete; 4- other)

105. Drop structure comments (eg. downstream scour depth):

$-$

$-$

$-$

$-$

$-$

$-$ 
106. Point/Side bar present? (Y or $N$. if $N$ type ctrl-n pb)Mid-bar distance:

Mid-bar width: -

Point bar extent: feet -

(US, UB, DS) to feet (US, UB, DS) positioned $\%$ LB to $\% \mathrm{RB}$ Material:

Point or side bar comments (Circle Point or Side; note additional bars, material variation, status, etc.):

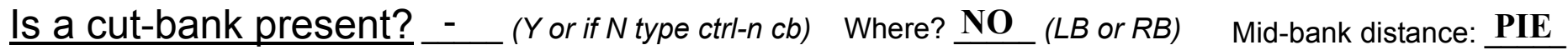
Cut bank extent: $\underline{\mathbf{R S}}$ feet __ (US, UB, DS) to feet ___ (US, UB, DS)

Bank damage: (1- eroded and/or creep; 2- slip failure; 3- block failure)

Cut bank comments (eg. additional cut banks, protection condition, etc.):

Is channel scour present? (Y or if $N$ type ctrl-n cs) Width 234 Depth: 7

Mid-scour distance: 1

Scour dimensions: Length 1

Scour comments (eg. additional scour areas, local scouring process, etc.):

342

$\mathbf{0}$

2

Are there major confluences? 1 ( 1 or if $N$ type ctrl-n $m c)$

Confluence 1: Distance chan Enters on nel (LB or RB)

Confluence 2: Distance rns

Enters on to ( $L B$ or $R B)$

Positioned $\mathbf{2}$ $\%$ LB to 1 $\%$ RB Confluence comments (eg. confluence name):

ut the same width as US and then narrows beyond $50 \mathrm{ft}$. DS. The DS reach is straight as it runs along the roadway of the North Branch Extension on the right bank. The right bank is protected with stone fill and the

\section{F. Geomorphic Channel Assessment}

107. Stage of reach evolution ba
1- Constructed

2- Stable

3- Aggraded

4- Degraded

5- Laterally unstable

6- Vertically and laterally unstable 
108. Evolution comments (Channel evolution not considering bridge effects; See HEC-20, Figure 1 for geomorphic descriptors):

nk also acts as the road embankment. The left bank side shows more erosional evidence than the right bank. The water is pooled under the bridge near the DS face and then changes to riffle at $20 \mathrm{ft}$. DS and remains riffle for more than $200 \mathrm{ft}$. The slope is constant and moderate. 


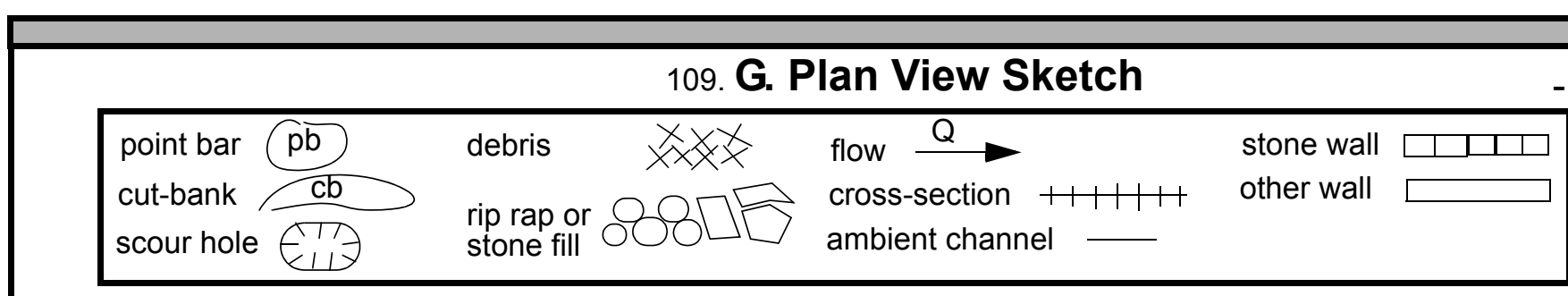


APPENDIX F:

SCOUR COMPUTATIONS 


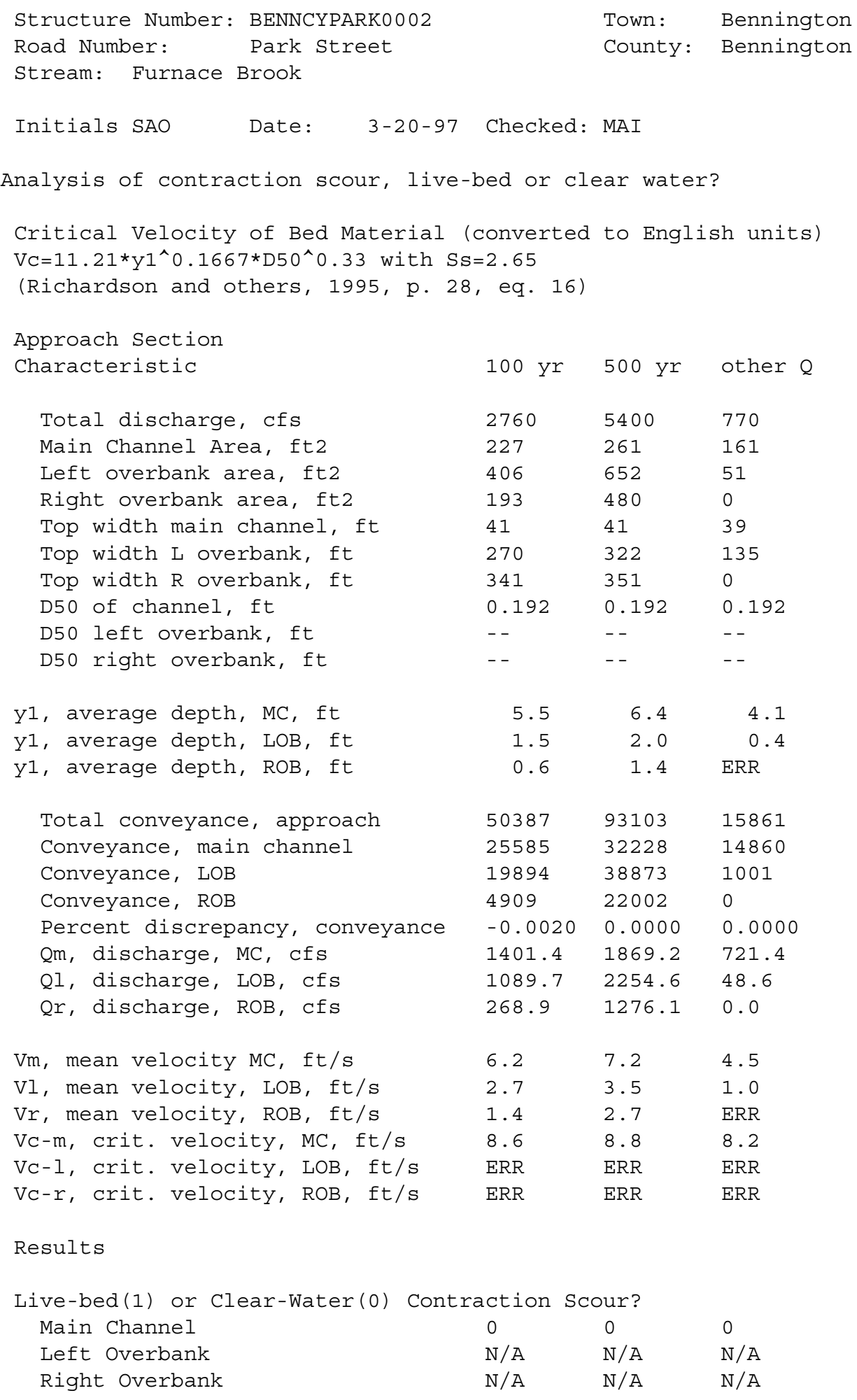


Clear water Contraction Scour in MAIN CHANNEL

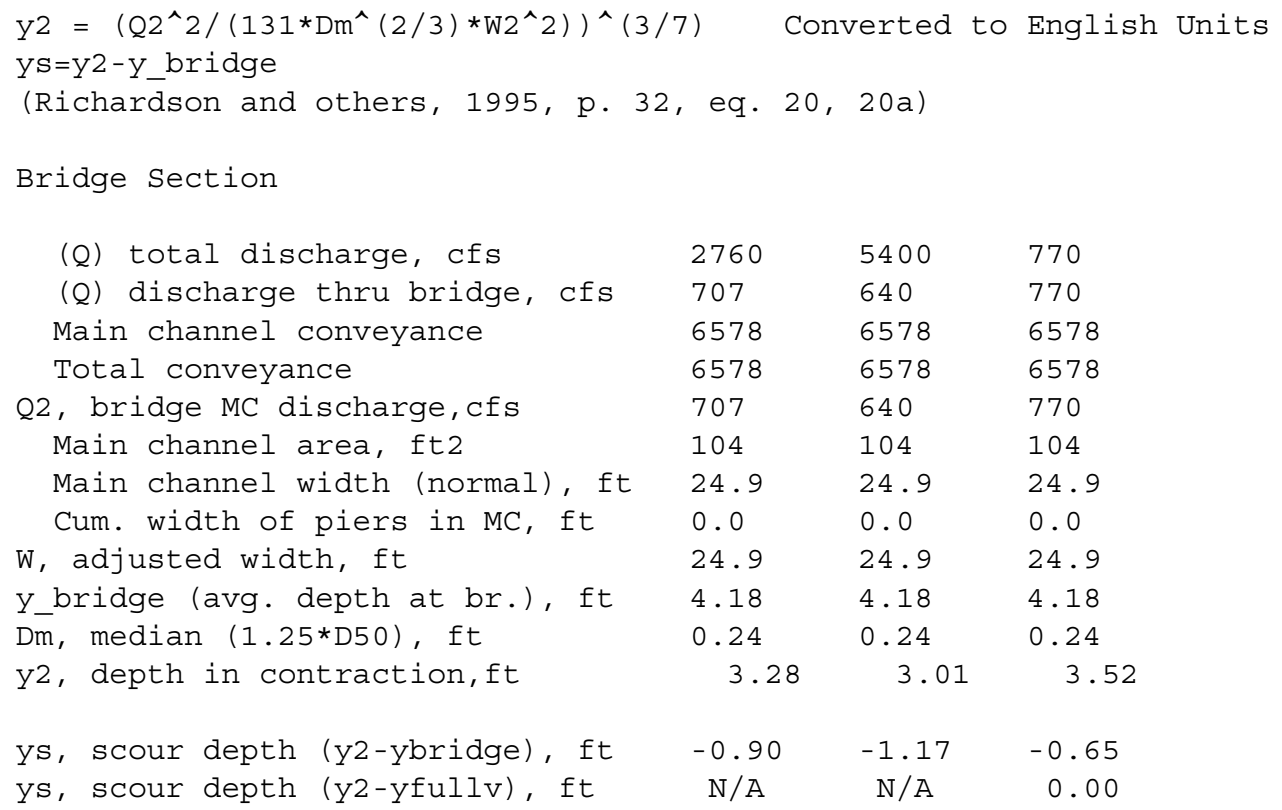

Pressure Flow Scour (contraction scour for orifice flow conditions)

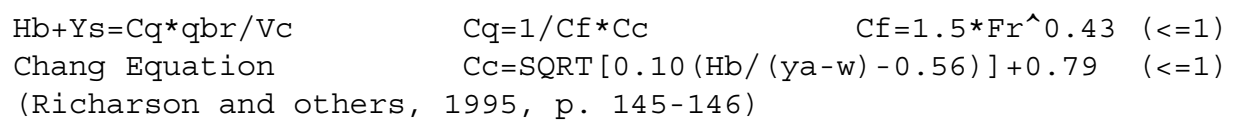

$\begin{array}{llll} & \text { Q100 } & \text { Q500 } & \text { OtherQ } \\ \text { Q, total, cfs } & 2760 & 5400 & 770 \\ \text { Q, thru bridge, cfs } & 707 & 640 & 770 \\ \text { Total Conveyance, bridge } & 6578 & 6578 & 6578 \\ \text { Main channel(MC) conveyance, bridge } 6578 & 6578 & 6578 \\ \text { Q, thru bridge MC, Cfs } & 707 & 640 & 770 \\ \text { Vc, critical velocity, ft/s } & 8.60 & 8.80 & 8.19 \\ \text { Vc, critical velocity, m/s } & 2.62 & 2.68 & 2.50 \\ \text { Main channel width (skewed), ft } & 24.9 & 24.9 & 24.9 \\ \text { Cum. width of piers in MC, ft } & 0.0 & 0.0 & 0.0 \\ \text { W, adjusted width, ft } & 24.9 & 24.9 & 24.9 \\ \text { qbr, unit discharge, ft2/s } & 28.4 & 25.7 & 30.9 \\ \text { qbr, unit discharge, m2/s } & 2.6 & 2.4 & 2.9 \\ \text { Area of full opening, ft2 } & 104.0 & 104.0 & 104.0 \\ \text { Hb, depth of full opening, ft } & 4.18 & 4.18 & 4.18 \\ \text { Hb, depth of full opening, m } & 1.27 & 1.27 & 1.27 \\ \text { Fr, Froude number, bridge MC } & 0.59 & 0.54 & 0.64 \\ \text { Cf, Fr correction factor (<=1.0) } & 1.00 & 1.00 & 1.00 \\ \text { Elevation of Low Steel, ft } & 498.22 & 498.22 & 498.22\end{array}$




$\begin{array}{llll}\text { Elevation of Bed, ft } & 494.04 & 494.04 & 494.04 \\ \text { Elevation of Approach, ft } & 501.36 & 502.19 & 499.71 \\ \text { Friction loss, approach, ft } & 0.4 & 0.8 & 0.17 \\ \text { Elevation of WS immediately US, ft } & 500.96 & 501.39 & 499.54 \\ \text { ya, depth immediately US, ft } & 6.92 & 7.35 & 5.50 \\ \text { ya, depth immediately US, m } & 2.11 & 2.24 & 1.68 \\ \text { Mean elevation of deck, ft } & 501.49 & 501.49 & 501.49 \\ \text { w, depth of overflow, ft (>=0) } & 0.00 & 0.00 & 0.00 \\ \text { Cc, vert contrac correction (<=1.0) } & 0.86 & 0.82 & 0.93 \\ \text { Ys, depth of scour, ft } & -0.32 & -0.61 & -0.12\end{array}$

\begin{tabular}{|c|c|c|c|}
\hline \multicolumn{4}{|c|}{$\begin{array}{l}\mathrm{DC}=\left[\left(1.94 * \mathrm{~V}^{\wedge} 2\right) /(5.75 * \log (12.27 * \mathrm{Y} / \mathrm{D} 90))^{\wedge} 2\right] /[0.03 *(165-62.4)] \\
\text { Depth to Armoring }=3 *(1 / \mathrm{PC}-1) \\
\text { (Federal Highway Administration, 1993) }\end{array}$} \\
\hline Downstream bridge face property & $100-y r$ & $500-y r$ & Other $Q$ \\
\hline Q, discharge thru bridge $\mathrm{MC}$, cfs & 707 & 640 & 770 \\
\hline Main channel area (DS), ft2 & 104 & 104 & 87 \\
\hline Main channel width (normal), ft & 24.9 & 24.9 & 24.9 \\
\hline Cum. width of piers, ft & 0.0 & 0.0 & 0.0 \\
\hline Adj. main channel width, ft & 24.9 & 24.9 & 24.9 \\
\hline D90, ft & 0.4652 & 0.4652 & 0.4652 \\
\hline D95, ft & 0.5989 & 0.5989 & 0.5989 \\
\hline Dc, critical grain size, ft & 0.2113 & 0.1731 & 0.3869 \\
\hline PC, Decimal percent coarser than Dc & 0.436 & 0.567 & 0.153 \\
\hline Depth to armoring, ft & 0.82 & 0.40 & 6.43 \\
\hline
\end{tabular}

Abutment Scour

Froehlich's Abutment Scour

$\mathrm{YS} / \mathrm{Y} 1=2.27 * \mathrm{~K} 1 * \mathrm{~K} 2 *\left(\mathrm{a}^{\prime} / \mathrm{Y} 1\right)^{\wedge} 0.43 * \mathrm{Fr} 1^{\wedge} 0.61+1$

(Richardson and others, 1995, p. 48, eq. 28)

Characteristic

Left Abutment

Right Abutment

100 yr Q 500 yr Q Other Q 100 yr Q 500 yr Q Other Q

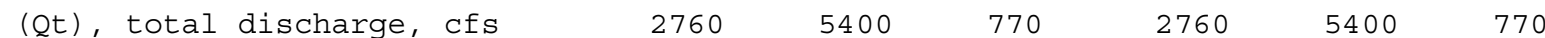

$\mathrm{a}^{\prime}$, abut.length blocking flow, ft $\begin{array}{llllll}276.1 & 328.1 & 141.8 & 9.4 & 9.4 & 7.5\end{array}$

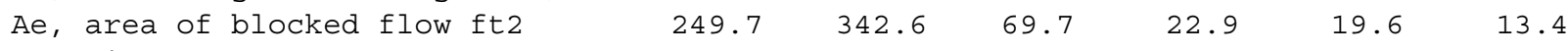

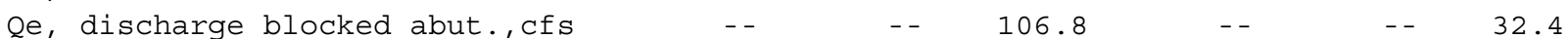

(If using Qtotal_overbank to obtain Ve, leave Qe blank and enter Ve and Fr manually)
$\mathrm{Ve},(\mathrm{Qe} / \mathrm{Ae}), \mathrm{ft} / \mathrm{s}$
$2.83 \quad 3.57$
1.53
4.11
4.85
2.42
ya, depth of $f / p$ flow, ft
0.90
1.04
0.49
2.44
2.09
1.79 


\begin{tabular}{|c|c|c|c|c|c|c|}
\hline $\begin{array}{l}--\operatorname{CoeII}, \mathrm{K \perp}, \text { IOr a.bl } \\
\mathrm{K} 1\end{array}$ & 1 & 1 & 1 & 1 & 1 & 1 \\
\hline --Angle (theta) of embankment $(<90$ & if abut. & points I & $\mathrm{DS} ;>90$ if & abut. poir & ints US) & \\
\hline theta & 80 & 80 & 80 & 100 & 100 & 100 \\
\hline K2 & 0.98 & 0.98 & 0.98 & 1.01 & 1.01 & 1.01 \\
\hline Fr, froude number $\mathrm{f} / \mathrm{p}$ flow & 0.396 & 0.435 & 0.385 & 0.431 & 0.494 & 0.319 \\
\hline ys, scour depth, ft & 14.36 & 17.70 & 7.51 & 8.43 & 8.05 & 5.58 \\
\hline \multicolumn{7}{|c|}{$\begin{array}{l}\left.\text { HIRE equation ( } \mathrm{a}^{\prime} / \mathrm{ya}>25\right) \\
\mathrm{ys}=4 * \mathrm{Fr} 0.33 * \mathrm{Y} 1 * \mathrm{~K} / 0.55 \\
(\mathrm{Richardson} \text { and others, 1995, p. 49, eq. 29) }\end{array}$} \\
\hline \multirow{8}{*}{$\begin{array}{l}\text { a' (abut length blocked, ft) } \\
\text { yl (depth f/p flow, ft) } \\
\text { a'/yl } \\
\text { Skew correction (p. 49, fig. 16) } \\
\text { Froude no. f/p flow } \\
\text { Ys w/ corr. factor K1/0.55: } \\
\text { vertical } \\
\text { vertical w/ ww's } \\
\text { spill-through }\end{array}$} & 276.1 & 328.1 & 141.8 & 9.4 & 9.4 & 7.5 \\
\hline & 0.90 & 1.04 & 0.49 & 2.44 & 2.09 & 1.79 \\
\hline & 305.29 & 314.21 & 288.48 & 3.86 & 4.51 & 4.20 \\
\hline & 0.97 & 0.97 & 0.97 & 1.02 & 1.02 & 1.02 \\
\hline & 0.40 & 0.44 & 0.39 & 0.43 & 0.49 & 0.32 \\
\hline & 4.69 & 5.58 & 2.52 & ERR & ERR & ERR \\
\hline & 3.84 & 4.58 & 2.07 & ERR & ERR & ERR \\
\hline & 2.58 & 3.07 & 1.39 & ERR & ERR & ERR \\
\hline \multicolumn{7}{|l|}{ Abutment riprap Sizing } \\
\hline \multirow{3}{*}{\multicolumn{7}{|c|}{$\begin{array}{l}\text { Isbash Relationship } \\
\mathrm{D} 50=\mathrm{Y} * \mathrm{~K} * \mathrm{Fr} 2 /(\mathrm{Ss}-1) \text { and } \mathrm{D} 50=\mathrm{Y}^{\star} \mathrm{K} *\left(\mathrm{Fr} \mathrm{F}^{\wedge}\right) \wedge 0.14 /(\mathrm{Ss}-1) \\
\text { (Richardson and others, 1995, p112, eq. 81,82) }\end{array}$}} \\
\hline & & & & & & \\
\hline & & & & & & \\
\hline Characteristic & Q100 & Q500 & Qother & Q100 & Q500 & Qother \\
\hline $\begin{array}{l}\text { Fr, Froude Number (DS) } \\
\quad \text { (Fr from the characteristic } V \text { and }\end{array}$ & $\begin{array}{l}0.59 \\
y \text { in con }\end{array}$ & $\begin{array}{c}0.54 \\
\text { ntracted }\end{array}$ & $\begin{array}{c}0.83 \\
\text { section- }-n\end{array}$ & $\begin{array}{l}0.59 \\
m c, \text { bridge }\end{array}$ & $\begin{array}{ll} & 0.54 \\
\text { e section) }\end{array}$ & 0.83 \\
\hline$y$, depth of flow in bridge (DS), ft & 4.18 & 4.18 & 3.49 & 4.18 & 4.18 & 3.49 \\
\hline \multicolumn{4}{|c|}{ Median stone Diameter for riprap at: left abutment } & \multicolumn{3}{|c|}{ right abutment, ft } \\
\hline Fr<=0.8 (vertical abut.) & 0.90 & 0.75 & ERR & 0.90 & 0.75 & ERR \\
\hline Fr>0.8 (vertical abut.) & ERR & ERR & 1.39 & $E R R$ & ERR & 1.39 \\
\hline Fr $<=0.8 \quad$ (spillthrough abut.) & 0.78 & 0.66 & ERR & 0.78 & 0.66 & ERR \\
\hline Fr>0.8 (spillthrough abut.) & ERR & ERR & 1.22 & ERR & ERR & 1.22 \\
\hline
\end{tabular}


